\title{
Expression of a fungal manganese peroxidase in Escherichia coli: a comparison between the soluble and refolded enzymes
}

Nan Wang, Kai Ren, Rong Jia*, Wenting Chen and Ruirui Sun

\begin{abstract}
Background: Manganese peroxidase (MnP) from Irpex lacteus F17 has been shown to have a strong ability to degrade recalcitrant aromatic pollutants. In this study, a recombinant MnP from I. lacteus F17 was expressed in Escherichia coli Rosetta (DE3) in the form of inclusion bodies, which were refolded to achieve an active enzyme. Further, we optimized the in vitro refolding conditions to increase the recovery yield of the recombinant protein production. Additionally, we attempted to express recombinant $\mathrm{MnP}$ in soluble form in E. coli, and compared its activity with that of refolded MnP.

Results: Refolded MnP was obtained by optimizing the in vitro refolding conditions, and soluble MnP was produced in the presence of four additives, TritonX-100, Tween-80, ethanol, and glycerol, through incubation at $16^{\circ} \mathrm{C}$. Hemin and $\mathrm{Ca}^{2+}$ supplementation was crucial for the activity of the recombinant protein. Compared with refolded $\mathrm{MnP}$, soluble $\mathrm{MnP}$ showed low catalytic efficiencies for $\mathrm{Mn}^{2+}$ and $\mathrm{H}_{2} \mathrm{O}_{2}$ substrates, but the two enzymes had an identical, broad range substrate specificity, and the ability to decolorize azo dyes. Furthermore, their enzymatic spectral characteristics were analysed by circular dichroism (CD), electronic absorption spectrum (UV-VIS), fluorescence and Raman spectra, indicating the differences in protein conformation between soluble and refolded MnP. Subsequently, size exclusion chromatography (SEC) and dynamic light scattering (DLS) analyses demonstrated that refolded MnP was a good monomer in solution, while soluble MnP predominantly existed in the oligomeric status.
\end{abstract}

Conclusions: Our results showed that two forms of recombinant MnP could be expressed in E. coli by varying the culture conditions during protein expression.

Keywords: Escherichia coli, Inclusion bodies, Kinetic properties, Manganese peroxidase, Protein expression, Protein refolding, Spectral characteristics

\section{Background}

Manganese peroxidase (MnP, E.C. 1.11.1.13) can be isolated from many species of white-rot fungi, and it catalyzes the oxidation of $\mathrm{Mn}^{2+}$ to $\mathrm{Mn}^{3+}$ in the presence of hydrogen peroxide $\left(\mathrm{H}_{2} \mathrm{O}_{2}\right)$ [1]. The produced $\mathrm{Mn}^{3+}$ is stabilized by organic acid and forms a $\mathrm{Mn}^{3+}$-organic acid complex that acts as a diffusible oxidizer, which in turn attacks a variety of aromatic compounds, including lignin, industrial dyes, and other organic contaminants [2, 3]. Crystal structures and spectroscopic

\footnotetext{
* Correspondence: ahdxjiarong@126.com

School of Life Science, Anhui University, 111 Jiulong Road, Economic and Technology Development Zone, Hefei, Anhui 230601, People's Republic of China
}

(c) The Author(s). 2016 Open Access This article is distributed under the terms of the Creative Commons Attribution 4.0 International License (http://creativecommons.org/licenses/by/4.0/), which permits unrestricted use, distribution, and reproduction in any medium, provided you give appropriate credit to the original author(s) and the source, provide a link to the Creative Commons license, and indicate if changes were made. The Creative Commons Public Domain Dedication waiver (http://creativecommons.org/publicdomain/zero/1.0/) applies to the data made available in this article, unless otherwise stated.

studies demonstrated that $\mathrm{MnP}$ is a two-domain, globular protein that consists of 11 or $12 \alpha$-helices. A heme prosthetic group, most commonly Fe protoporphyrin IX, is located between the two domains [4]. Two $\mathrm{Ca}^{2+}$-binding sites, which provide structural support, are located on both sides of the heme group, and a Mn-binding site, which is required for catalysis, is located near the internal heme propionate $[4,5]$. In addition, $\mathrm{MnP}$ has four or five disulfide bridges that stabilize its protein structure [6].

Commercial applications of fungal $\mathrm{MnP}$ are mainly based on the high level of protein expression of some fungal strains. However, as described by Saroj et al. [7], the yield of native $\mathrm{MnP}$ in its native hosts was too low, 
and approximately 1.0 to $5 \mathrm{mg}$ of purified recombinant $\mathrm{MnP}$ was obtained per liter of extracellular culture fluid. And an appropriate medium composition and critical culture conditions are necessary to induce fungi to produce ligninolytic enzymes [8]. Therefore, improving the enzyme yield and reducing the cost of preparation are needed to meet the requirements of commercial use. In recent years, the production of recombinant proteins has been among the main options. Both homologous and heterologous expression in prokaryotic and eukaryotic systems have been used to achieve the overproduction of MnP. For instance, homologous expression systems in Phanerochaete chrysosporium [9] and Pleurotus ostreatus [10] used a primary metabolic promoter, but the resulting MnP yield was still low. Pichia pastoris, which is a common heterologous expression system, has been used to produce active $\mathrm{MnP}$ at a maximum yield of only $120 \mathrm{U} / \mathrm{L}$ [11]. In addition, numerous studies have used Escherichia coli to express MnP [12, 13]. In general, the recombinant protein accumulated in the form of in inclusion bodies is an inactive, insoluble form; functional, active $\mathrm{MnP}$ could be obtained by in vitro refolding based on the incorporation of exogenous hemin and $\mathrm{Ca}^{2+}$. Nevertheless, an efficient process to produce high yields of the recombinant enzyme is still lacking, even after optimizing the refolding procedure [12, 14]. Additionally, refolding is a result of trial and error, and it requires much effort to obtain a renatured protein. Therefore, it is of great interest and importance to explore soluble protein production in E. coli. In this regard, alternative methods have been examined, such as choosing a suitable vector and host [15], changing the type of promoter [16], switching the location of an affinity tag [16], decreasing the growth temperature [17], optimizing codon usage [18], adding osmolytes to the expression medium [19], coexpressing chaperones [20], and site-directed mutagenesis [21]. However, thus far, no strategy has yielded soluble MnP in E. coli.

Irpex lacteus $\mathrm{F} 17$ is a local, MnP-producing, white-rot basidiomycete fungus, and an MnP-encoding gene, imnp, from this species has been cloned and expressed in E. coli by our laboratory [22]. As expected, the expressed protein accumulated in an insoluble form as inclusion bodies. Subsequent in vitro refolding and incorporating exogenous hemin into the recombinant protein led to the formation of biologically active $\mathrm{MnP}$ [22]. In the present study, we further optimized the in vitro refolding conditions to improve the efficiency of renaturation from inclusion bodies using a one-factor-at-a-time method and an orthogonal experimental design based on our previous results. In parallel, we used a strategy to express $\mathrm{MnP}$ in a soluble form in $E$. coli by adding chemicals to the cultures, and simultaneously lowering the growth temperature during protein expression.
Additionally, the biochemical and spectroscopic characterizations of soluble and refolded MnP were analyzed, and their abilities to decolorize azo dyes were investigated.

\section{Results \\ Optimal conditions for refolding MnP from inclusion bodies}

In the single-factor experiment, the refolding efficiency was estimated from different shades of red in a 48 deepwell plate by changing various refolding parameters, as well as their concentrations or quantities, to preliminarily screen for the important factor(s). The results indicated that urea, GSSG, glycerol, and $\mathrm{pH}$ significantly affected the enzyme activity, while $\mathrm{MnSO}_{4}$ and $\mathrm{KCl}$ had no obvious effects. No activity was detected if $\mathrm{CaCl}_{2}$ and hemin were omitted from the refolding solution. To search for the optimal combination of significant factors, as well as their concentrations or quantities, an orthogonal experiment design, which consisted of six factors (urea, $\mathrm{CaCl}_{2}$, hemin, glycerol, GSSG, and $\mathrm{pH}$ ), was tested at three levels using the $\mathrm{L}_{18}\left(3^{6}\right)$ orthogonal array. Details of the three levels for each factor were shown in Table 1. Eighteen experiments according to the $\mathrm{L}_{18}\left(3^{6}\right)$ orthogonal array were performed. Results of the effects of the six factors on enzymatic specific activity were presented in Table 2. $K_{1}$ was the sum of the specific activities for each factor when the factor level is 1 , and $k_{1}$ was the average number of $K_{1}$, and so on, for $K_{2}$ and $K_{3}$, as well as for $k_{2}$ and $k_{3}$. Meanwhile, $R$ was the difference of the largest and smallest $k$ values of each factor. A large value of $R$ indicates that the effect of factor on the results is significant. As shown in Table 2, assay "6" produced the maximum $\mathrm{MnP}$ specific activity of $3.63 \mathrm{U} / \mathrm{mg}$, which was almost twofold higher than that of the optimized condition obtained in the single-factor experiment $(1.88 \mathrm{U} / \mathrm{mg})$. In addition, according to the maximum of $k_{1}, k_{2}$ and $k_{3}$ of each factor, a combination (i.e., $1.0 \mathrm{M}$ urea, $150 \mathrm{mM} \mathrm{CaCl}_{2}$, $10 \mu \mathrm{M}$ hemin, $10 \%$ glycerol, $0.5 \mathrm{mM}$ GSSG, and $\mathrm{pH} 8.5$ ) was further tested, and the specific activity of refolded $\mathrm{MnP}$ was $2.65 \mathrm{U} / \mathrm{mg}$, indicating that it was inferior to experiment " 6 ". Thus, the optimized refolding solution comprised $1.5 \mathrm{M}$ urea, $150 \mathrm{mM} \mathrm{CaCl}, 25 \mu \mathrm{M}$ hemin, $10 \%$ glycerol, $0.5 \mathrm{mM}$ GSSG, $0.05 \mathrm{mM} \mathrm{MnSO}_{4}$, and $20 \mathrm{mM}$ $\mathrm{KCl}$ in $50 \mathrm{mM}$ Tris- $\mathrm{HCl}(\mathrm{pH} 8.5)$ at $4{ }^{\circ} \mathrm{C}$ for $24 \mathrm{~h}$. The value of $\mathrm{R}$ in Table 2 showed that $\mathrm{pH}$ and GSSG had important effects on specific activity of refolding MnP.

\begin{tabular}{|c|c|c|c|c|c|c|}
\hline Factor level & $\begin{array}{l}\text { A } \\
\text { Urea } \\
\text { (M) }\end{array}$ & $\begin{array}{l}\mathrm{B} \\
\mathrm{CaCl}_{2} \\
(\mathrm{mM})\end{array}$ & $\begin{array}{l}\mathrm{C} \\
\text { Hemin } \\
(\mu \mathrm{M})\end{array}$ & $\begin{array}{l}\text { D } \\
\text { Glycerol } \\
(\%)\end{array}$ & $\begin{array}{l}\mathrm{E} \\
\text { GSSG } \\
(\mathrm{mM})\end{array}$ & $\begin{array}{l}\mathrm{F} \\
\mathrm{pH}\end{array}$ \\
\hline 1 & 1.0 & 75 & 5.0 & 10 & 0.5 & 8.0 \\
\hline 2 & 1.5 & 100 & 10 & 15 & 0.7 & 8.5 \\
\hline 3 & 2.0 & 150 & 25 & 20 & 1.0 & 9.0 \\
\hline
\end{tabular}


Table 2 Effect of six factors on specific activity of refolded MnP

\begin{tabular}{|c|c|c|c|c|c|c|c|}
\hline Experiment & $\begin{array}{l}\text { A } \\
\text { Urea } \\
\text { (M) } \\
\end{array}$ & $\begin{array}{l}\mathrm{B} \\
\mathrm{CaCl}_{2} \\
(\mathrm{mM})\end{array}$ & $\begin{array}{l}\mathrm{C} \\
\text { Hemin } \\
(\mu \mathrm{M})\end{array}$ & $\begin{array}{l}\text { D } \\
\text { Glycerol } \\
(\%)\end{array}$ & $\begin{array}{l}\text { E } \\
\text { GSSG } \\
(\mathrm{mM})\end{array}$ & $\begin{array}{l}\mathrm{F} \\
\mathrm{pH}\end{array}$ & $\begin{array}{l}\text { Specific activity } \\
(\mathrm{U} / \mathrm{mg})\end{array}$ \\
\hline 1 & 1 & 1 & 1 & 1 & 1 & 1 & $1.63 \pm 0.23$ \\
\hline 2 & 1 & 2 & 2 & 2 & 2 & 2 & $1.89 \pm 0.59$ \\
\hline 3 & 1 & 3 & 3 & 3 & 3 & 3 & $0.65 \pm 0.02$ \\
\hline 4 & 2 & 1 & 1 & 2 & 2 & 3 & $0.86 \pm 0.15$ \\
\hline 5 & 2 & 2 & 2 & 3 & 3 & 1 & $0.86 \pm 0.04$ \\
\hline 6 & 2 & 3 & 3 & 1 & 1 & 2 & $3.63 \pm 0.19$ \\
\hline 7 & 3 & 1 & 2 & 1 & 3 & 2 & $2.04 \pm 0.24$ \\
\hline 8 & 3 & 2 & 3 & 2 & 1 & 3 & $1.10 \pm 0.06$ \\
\hline 9 & 3 & 3 & 1 & 3 & 2 & 1 & $1.01 \pm 0.25$ \\
\hline 10 & 1 & 1 & 3 & 3 & 2 & 2 & $2.23 \pm 0.39$ \\
\hline 11 & 1 & 2 & 1 & 1 & 3 & 3 & $1.83 \pm 0.25$ \\
\hline 12 & 1 & 3 & 2 & 2 & 1 & 1 & $3.38 \pm 0.06$ \\
\hline 13 & 2 & 1 & 2 & 3 & 1 & 3 & $1.02 \pm 0.23$ \\
\hline 14 & 2 & 2 & 3 & 1 & 2 & 1 & $0.86 \pm 0.07$ \\
\hline 15 & 2 & 3 & 1 & 2 & 3 & 2 & $2.03 \pm 0.10$ \\
\hline 16 & 3 & 1 & 3 & 2 & 3 & 1 & $0.96 \pm 0.12$ \\
\hline 17 & 3 & 2 & 1 & 3 & 1 & 2 & $1.52 \pm 0.36$ \\
\hline 18 & 3 & 3 & 2 & 1 & 2 & 3 & $1.16 \pm 0.09$ \\
\hline$K_{1}$ & 11.61 & 8.742 & 8.88 & 11.148 & 12.282 & 8.7 & \\
\hline $\mathrm{K}_{2}$ & 9.258 & 8.058 & 10.35 & 10.218 & 8.01 & 13.338 & \\
\hline $\mathrm{K}_{3}$ & 7.788 & 11.862 & 9.432 & 7.29 & 8.37 & 6.618 & \\
\hline$k_{1}$ & 1.935 & 1.457 & 1.48 & 1.858 & 2.047 & 1.45 & \\
\hline$k_{2}$ & 1.543 & 1.343 & 1.725 & 1.703 & 1.335 & 2.223 & \\
\hline$k_{3}$ & 1.298 & 1.977 & 1.572 & 1.215 & 1.395 & 1.103 & \\
\hline$R$ & 0.637 & 0.634 & 0.245 & 0.643 & 0.712 & 1.12 & \\
\hline
\end{tabular}

Specific activity was obtained from the orthogonal design experiment. Each value is the average of three independent runs of experiment $\mathrm{K}_{1}$ represents the sum of the specific activity of each factor if the factor level is $1, \mathrm{~K}_{2}$ represents the sum of the specific activity of each factor if the factor level is 2 , and so $K_{3} . k_{1}$ represents the average number of $K_{1}$, and so on, for $k_{2}$ and $k_{3}$. $R$ represents the difference of the largest and smallest $k$ values of each factor

\section{Optimal conditions for expressing soluble MnP}

Similarly, the procedure searching for the optimal expression conditions for soluble MnP was similar to that used to optimize MnP refolding from inclusion bodies. According to the results of a single-factor experiment, Triton X-100 played a significant role in the expression of soluble $\mathrm{MnP}$. Tween-80, glycerol, and ethanol improved the activity of soluble MnP, while sorbitol, L-proline, and glycine had no distinct impact on the expression of soluble MnP. Thus, an orthogonal experimental design comprising four factors (Triton X-100, Tween-80, glycerol, and ethanol), with each factor being tested at three levels, was performed using the $\mathrm{L}_{9}\left(3^{4}\right)$ orthogonal array (Table 3$)$. Results of the effects of the four factors on enzymatic specific activity were presented in Table 4. As shown, assay "1" produced a specific activity $(0.411 \mathrm{U} / \mathrm{mg})$, which was higher than that of the optimized condition obtained in the single-factor experiment $(0.391 \mathrm{U} / \mathrm{mg})$. In addition, according to the maximum of $k_{1}, k_{2}$ and $k_{3}$ of each factor in Table 4 , a combination was further tested, which resulted in a maximum of $0.56 \mathrm{U} / \mathrm{mg}$, higher than the specific activity of experiment " 1 ". As a result, the production of soluble MnP could be induced by the addition of $0.3 \mathrm{mM}$ IPTG, along with $0.25 \%$ Triton X-100, $0.25 \%$ Tween-80, $0.5 \%$ glycerol, and $1 \%$ ethanol, to the cell cultures, followed by cultivation for $16 \mathrm{~h}$ at $16{ }^{\circ} \mathrm{C}$. The value of $\mathrm{R}$ in Table 4 indicated that

Table 3 Contents of orthogonal factors and levels $L_{9}\left(3^{4}\right)$

\begin{tabular}{lllll}
\hline $\begin{array}{l}\text { Factor } \\
\text { level }\end{array}$ & $\mathrm{A}$ & $\mathrm{B}$ & $\mathrm{C}$ & $\mathrm{D}$ \\
& Triton X-100 & Tween-80 & Glycerol & Ethanol \\
\hline & $(\%)$ & $(\%)$ & $(\%)$ & $(\%)$ \\
2 & 0.25 & 0.25 & 0.25 & 1.0 \\
3 & 0.5 & 0.5 & 0.5 & 1.5 \\
\hline
\end{tabular}


Table 4 Effect of four factors on specific activity of soluble MnP

\begin{tabular}{|c|c|c|c|c|c|}
\hline \multirow[t]{3}{*}{ Experiment } & \multirow{3}{*}{$\begin{array}{l}\text { A } \\
\text { Triton X-100 } \\
(\%)\end{array}$} & \multirow{3}{*}{$\begin{array}{l}\text { B } \\
\text { Tween-80 } \\
\text { (\%) }\end{array}$} & \multirow{3}{*}{$\begin{array}{l}\text { C } \\
\text { Glycerol } \\
(\%)\end{array}$} & \multirow{3}{*}{$\begin{array}{l}\text { D } \\
\text { Ethanol } \\
(\%)\end{array}$} & \multirow{3}{*}{$\begin{array}{l}\text { Specific activity } \\
(\mathrm{U} / \mathrm{mg})\end{array}$} \\
\hline & & & & & \\
\hline & & & & & \\
\hline 1 & 1 & 1 & 1 & 1 & $0.411 \pm 0.03$ \\
\hline 2 & 1 & 2 & 2 & 2 & $0.355 \pm 0.02$ \\
\hline 3 & 1 & 3 & 3 & 3 & $0.361 \pm 0.14$ \\
\hline 4 & 2 & 1 & 2 & 3 & $0.320 \pm 0.03$ \\
\hline 5 & 2 & 2 & 3 & 1 & $0.185 \pm 0.01$ \\
\hline 6 & 2 & 3 & 1 & 2 & $0.208 \pm 0.07$ \\
\hline 7 & 3 & 1 & 3 & 2 & $0.167 \pm 0.02$ \\
\hline 8 & 3 & 2 & 1 & 3 & $0.121 \pm 0.03$ \\
\hline 9 & 3 & 3 & 2 & 1 & $0.252 \pm 0.27$ \\
\hline $\mathrm{K}_{1}$ & 1.127 & 0.897 & 0.741 & 0.849 & \\
\hline $\mathrm{K}_{2}$ & 0.714 & 0.66 & 0.927 & 0.729 & \\
\hline $\mathrm{K}_{3}$ & 0.54 & 0.822 & 0.714 & 0.801 & \\
\hline$k_{1}$ & 0.376 & 0.299 & 0.247 & 0.283 & \\
\hline$k_{2}$ & 0.238 & 0.22 & 0.309 & 0.243 & \\
\hline$k_{3}$ & 0.18 & 0.274 & 0.238 & 0.267 & \\
\hline $\mathrm{R}$ & 0.196 & 0.079 & 0.071 & 0.04 & \\
\hline
\end{tabular}

Specific activity was obtained from the orthogonal design experiment. Each value is the average of three independent runs of experiment

$\mathrm{K}_{1}$ represents the sum of the specific activity of each factor if the factor level is 1. $K_{2}$ represents the sum of the specific activity of each factor if the factor level is 2 , and so $K_{3} . k_{1}$ represents the average number of $K_{1}$, and so on, for $k_{2}$ and $k_{3}$. $R$ represents the difference of the largest and smallest $k$ values of each factor

Triton X-100 was the most important factor for expressing soluble MnP in E. coli.

\section{Purification of soluble and refolded $\mathrm{MnP}$}

Two forms of the recombinant MnP were obtained from $E$. coli under the optimal conditions for insoluble inclusion body and for soluble protein, respectively. Both soluble and refolded $\mathrm{MnP}$, each with a C-terminal, sixhistidine tag, were purified by Ni-NTA affinity chromatography. They were visualized as a single band on SDSPAGE, and they exhibited a similar molecular weight of $43 \mathrm{kDa}$ (Fig. 1). Under the optimal refolding conditions, the refolding yield of dialyzed $\mathrm{MnP}$ obtained from inclusion bodies was $13 \%$, and the yield of purified MnP was $2.4 \%$ (Table 5). The final recovery, which was calculated from the total activity, was approximately $78 \%$. For soluble $\mathrm{MnP}$, approximately $1.5 \mathrm{mg}$ of purified, active MnP was obtained from $2 \mathrm{~L}$ of $E$. coli fermentation broth.

\section{Biochemical characterization of soluble and refolded MnP Enzyme kinetic properties}

Table 6 shows the kinetic constants of soluble and refolded $\mathrm{MnP}$ using $\mathrm{Mn}^{2+}$ and $\mathrm{H}_{2} \mathrm{O}_{2}$ as substrates. The $K_{m}(336 \mu \mathrm{M})$ of soluble $\mathrm{MnP}$ for $\mathrm{Mn}^{2+}$ was higher than that $(148 \mu \mathrm{M})$ of refolded $\mathrm{MnP}$, and the $K_{m}(23.5 \mu \mathrm{M})$ of soluble $\mathrm{MnP}$ for $\mathrm{H}_{2} \mathrm{O}_{2}$ was reduced $90 \%$ than that $(234.5 \mu \mathrm{M})$ of refolded $\mathrm{MnP}$. The $k_{\text {cat }} / K_{m}$ values of refolded $\mathrm{MnP}$ for $\mathrm{Mn}^{2+}$ and $\mathrm{H}_{2} \mathrm{O}_{2}$ were 12.2-fold and 2.9-fold higher than those of soluble MnP, respectively. However, the $k_{\text {cat }} / K_{m}$ values of the two forms of recombinant MnP were both lower than that of the native $\mathrm{MnP}$ for $\mathrm{Mn}^{2+}\left(9.62 \times 10^{3}(\mathrm{mmol})^{-1} \mathrm{~L} \mathrm{~s}^{-1}\right)$ and $\mathrm{H}_{2} \mathrm{O}_{2}$ $\left(5.22 \times 10^{4}(\mathrm{mmol})^{-1} \mathrm{~L} \mathrm{~s}^{-1}\right)$, respectively.

\section{Temperature stability and $\mathrm{pH}$ optimum}

As illustrated in Fig. 2a, soluble MnP showed less than $65 \%$ relative activity (the ratio of actual to maximum activity) in a broad $\mathrm{pH}$ range (2.2-6.6). However, a rapid increase in activity occurred at pHs higher than 7.0, and the optimal pH was 8.0. Additionally, the enzyme was optimally stable at $\mathrm{pH} 5.0$ during a 6 -h incubation in citratephosphate buffer ( $\mathrm{pH}$ 5.0). Unlike soluble MnP, refolded $\mathrm{MnP}$ showed maximum activity at $\mathrm{pH}$ 6.5, and retained more than $80 \%$ of its activity over a wide range of $\mathrm{pH}$ (3.07.0). In addition, the $\mathrm{pH}$ stability of refolded $\mathrm{MnP}$ was superior to that of soluble MnP (Fig. 2b). As shown in Fig. 2c and $\mathrm{d}$, soluble $\mathrm{MnP}$ exhibited the highest activity at $45^{\circ} \mathrm{C}$, and retained $90 \%$ of its activity after a 6-h incubation at temperatures below $25{ }^{\circ} \mathrm{C}$. Refolded MnP displayed optimum activity at $15{ }^{\circ} \mathrm{C}$ and was very stable below $35^{\circ} \mathrm{C}$; no activity was detected at $45^{\circ} \mathrm{C}$ after incubation for $6 \mathrm{~h}$.

\section{Substrate specificity}

To examine the substrate specificity of soluble and refolded MnP, the monocyclic phenolic compounds DMP and guaiacol, as well as the polycyclic compound ABTS, were selected as substrates. The results showed that the oxidation of these substrates by soluble MnP was similar to that for refolded $\mathrm{MnP}$, and they were all dependent upon $\mathrm{Mn}^{2+}$ (Table 7). The results indicated that both of the soluble and refolded $\mathrm{MnP}$ are powerful oxidants that are capable of oxidizing aromatic compounds.

\section{Decolorization of Acid Red 18 and Orange G}

Acid Red 18 and Orange G, as important azo dyes, have been extensively used in the textile, printing, food, and drug industries, and they are usually released into industrial wastewater. Accordingly, we chose them to examine the degradation capability of soluble and refolded MnP. As shown in Fig. 3, the decolorization efficiency of Acid Red 18 was $63 \pm 1.41 \%$ for the soluble MnP after a 60 -min reaction at $\mathrm{pH} 4.0$ and $35{ }^{\circ} \mathrm{C}$, while the decolorization efficiency was $78.5 \pm 0.71 \%$ for the refolded MnP. Moreover, for Orange G, $35 \pm 0.01$ and $56 \pm 0.03 \%$ decolorization efficiencies were observed for soluble and refolded $\mathrm{MnP}$, respectively. However, the decolorization efficiencies of the two forms of recombinant $\mathrm{MnP}$ were both lower than that of the native $\mathrm{MnP}$ for Acid Red $18(84 \pm 1.3 \%)$ and Orange G (68 \pm $0.6 \%)$, respectively. 


\section{$\operatorname{Mr}(k D a)$ lane $1 \quad$ lane 2}

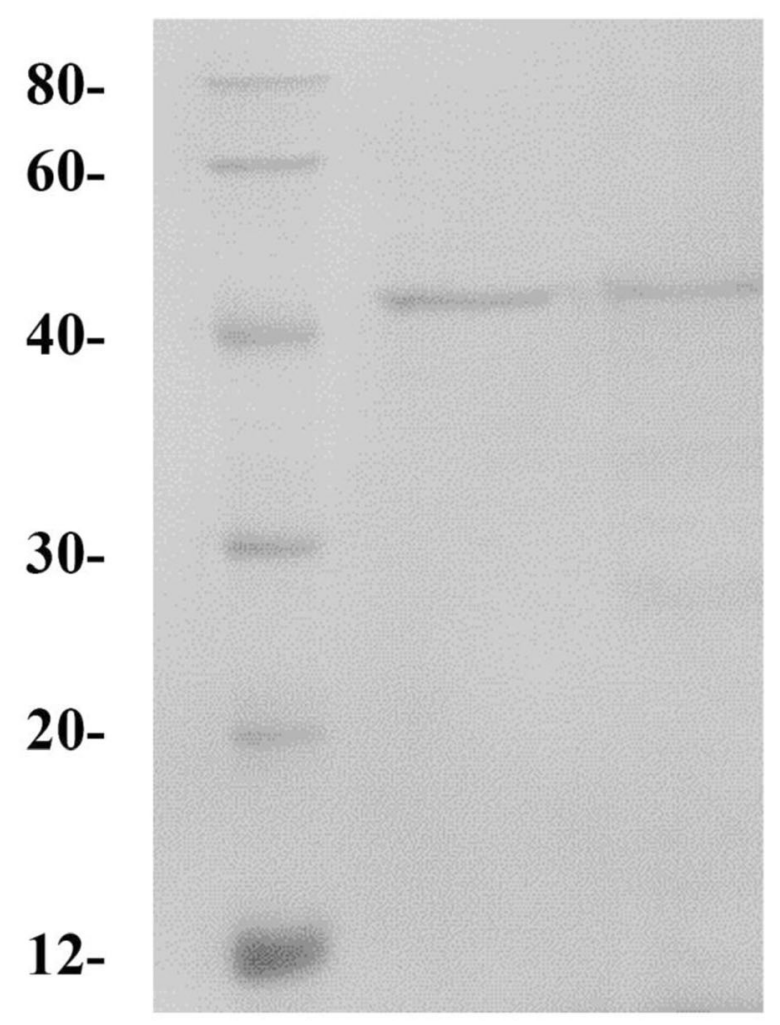

Fig. 1 SDS-PAGE of recombinant MnP purified by a $\mathrm{Ni}^{2+}$ His-tag column. Lane M: protein standards; Lane 1: purified refolded MnP; Lane 2: purified soluble MnP

\section{Spectroscopic characterization of soluble and refolded $\mathrm{MnP}$ CD spectra and UV-VIS spectra}

It is well known that a circular dichroism (CD) spectrum in far-UV region provides information on the secondary structure of a protein. The far-UV CD spectra of soluble and refolded $\mathrm{MnP}$ exhibited two negative ellipticity bands at $208 \mathrm{~nm}$ and $222 \mathrm{~nm}$ (Fig. 4a), respectively, displaying characteristics of an $\alpha$-helical structure, but they showed notable differences. Furthermore, the $\alpha$-helix and the $\beta$-sheet contents of the two MnPs were calculated using the SELCON3 program, and the data showed that the helical content of soluble MnP (18.7\%) was lower than that of refolded MnP (24.3\%), whereas the $\beta$ sheet content of soluble MnP (27\%) was higher than that of refolded MnP (18.2\%).
To evaluate the secondary structure of soluble and refolded $\mathrm{MnP}$, we investigated the far-UV CD spectrum of the purified, native MnP from fungus Irpex lacteus F17 using CD spectrometer under the same conditions, as shown in Fig. 4a. The native fungal MnP was obtained according to our previous experimental protocols described in the literature [23]. On the basis of the analysis of SELCON3 program, 39.7\% $\alpha$-helix and $13.7 \% \beta$-sheet were involved in the structure of $\mathrm{CD}$ of native MnP produced by fungus Irpex lacteus F17.

The UV-VIS spectrum of soluble MnP was similar to that of refolded MnP (Fig. 4b); however, their absorption intensities obviously differed. Refolded MnP exhibited a Soret peak at $408 \mathrm{~nm}, \mathrm{Q}$ band at $527 \mathrm{~nm}$ and a charge transfer $(\mathrm{CT})$ band at $631 \mathrm{~nm}$, while soluble MnP shifted the Soret peak to $410 \mathrm{~nm}, \mathrm{Q}$ band to $536 \mathrm{~nm}$ with a tiny $\mathrm{CT}$ band at $631 \mathrm{~nm}$, and the absorbance of soluble MnP was clearly lower than that of refolded MnP. The Reinheitszahl $\left(R_{Z}\right)$ values (calculated from the A408/A280 and A410/A280 absorption ratios) for the purified, refolded $\mathrm{MnP}$ and soluble $\mathrm{MnP}$ were 2.5 and 1.1, respectively, indicating that the heme environment of the two enzymes differed. These results are in agreement with the lower specific activity of soluble MnP compared with refolded MnP, as shown in the inset of Fig. 4b.

\section{Fluorescence spectra}

Figure 5 showed the fluorescence spectra of soluble and refolded $\mathrm{MnP}$ at room temperature following excitation at $295 \mathrm{~nm}$. As shown, refolded $\mathrm{MnP}$ had a maximum emission at $337 \mathrm{~nm}$, whereas the maximum emission of soluble MnP occurred at $341 \mathrm{~nm}$, which represented a 4-nm red shift and an increased quantum yield.

\section{Raman spectra}

Figure 6 represented the Raman spectra of soluble and refolded $\mathrm{MnP}$ at room temperature following excitation at $785 \mathrm{~nm}$. The C-C stretching vibration near $890-945 \mathrm{~cm}^{-1}$ of Raman spectra indicated that soluble and refolded MnP were primarily $\alpha$-helix structures. The relative weak amide I bands centered at $1598 \mathrm{~cm}^{-1}$ and $1675 \mathrm{~cm}^{-1}$ were both correlated with an increase in $\beta$-sheet contents for soluble $\mathrm{MnP}$, while the $\beta$-sheet structure of refolded MnP was involved in an amide I band centered at $1680 \mathrm{~cm}^{-1}$. The band at $1070 \mathrm{~cm}^{-1}$ exhibited in soluble $\mathrm{MnP}$ and the bands at 1101 and $1126 \mathrm{~cm}^{-1}$ presented in refolded MnP, originated from $\mathrm{C}-\mathrm{N}$ stretching vibrations, revealed some

Table 5 Isolation and purification of MnP from inclusion bodies

\begin{tabular}{lccccc}
\hline Sample & Protein concentration $(\mathrm{mg} / \mathrm{ml})$ & Protein $(\mathrm{mg})$ & Specific activity $(\mathrm{U} / \mathrm{mg})$ & Total activity $(\mathrm{U})$ & Yield $(\%)$ \\
\hline Inclusion body & 18.7 & 93.5 & & 37.5 & 100 \\
Dialyzed & 0.43 & 12.35 & 3.04 & 29.15 & 78 \\
Ni-NTA & 0.076 & 2.26 & 12.9 & 2 & 7 \\
\hline
\end{tabular}


Table 6 Kinetic parameters of refolded and soluble MnP

\begin{tabular}{|c|c|c|c|c|}
\hline Enzyme & $K m\left(\mathrm{Mn}^{2+}\right) \mu \mathrm{mol} \mathrm{L}$ & $V \max \left(\mathrm{Mn}^{2+}\right) \mu \mathrm{mol} \mathrm{L}{ }^{-1} \min ^{-1}$ & Kcat $\left(\mathrm{Mn}^{2+}\right) \mathrm{s}^{-1}$ & Kcat $/ K m\left(\mathrm{Mn}^{2+}\right)(\mathrm{mmol})^{-1} \mathrm{~L} \mathrm{~s}^{-1}$ \\
\hline Refolded MnP & $148 \pm 7.1$ & $1276 \pm 23.3$ & $141.9 \pm 2.62$ & $930 \pm 30$ \\
\hline Soluble MnP & $336 \pm 8.0$ & $236.6 \pm 24.7$ & $25.6 \pm 2.7$ & $76 \pm 9.9$ \\
\hline Native MnP & $100.7 \pm 0.87$ & $1116.3 \pm 18.3$ & $969 \pm 22.6$ & $9620 \pm 420$ \\
\hline Enzyme & $\mathrm{Km}\left(\mathrm{H}_{2} \mathrm{O}_{2}\right) \mu \mathrm{mol} \mathrm{L}-1$ & $V \max \left(\mathrm{H}_{2} \mathrm{O}_{2}\right) \mu \mathrm{mol} \mathrm{L}{ }^{-1} \min ^{-1}$ & Kcat $\left(\mathrm{H}_{2} \mathrm{O}_{2}\right) \mathrm{s}^{-1}$ & $\mathrm{Kcat} / \mathrm{Km}\left(\mathrm{H}_{2} \mathrm{O}_{2}\right)(\mathrm{mmol})^{-1} \mathrm{~L} \mathrm{~s}^{-1}$ \\
\hline Refolded MnP & $234.5 \pm 12$ & $3326.5 \pm 179$ & $554.4 \pm 29$ & $2370 \pm 7$ \\
\hline Soluble MnP & $23.5 \pm 4.9$ & $308.1 \pm 26.9$ & $19 \pm 1.7$ & $820 \pm 100$ \\
\hline Native MnP & $30.7 \pm 4.4$ & $1844.5 \pm 25$ & $1601.1 \pm 34.8$ & $52200 \pm 450$ \\
\hline
\end{tabular}
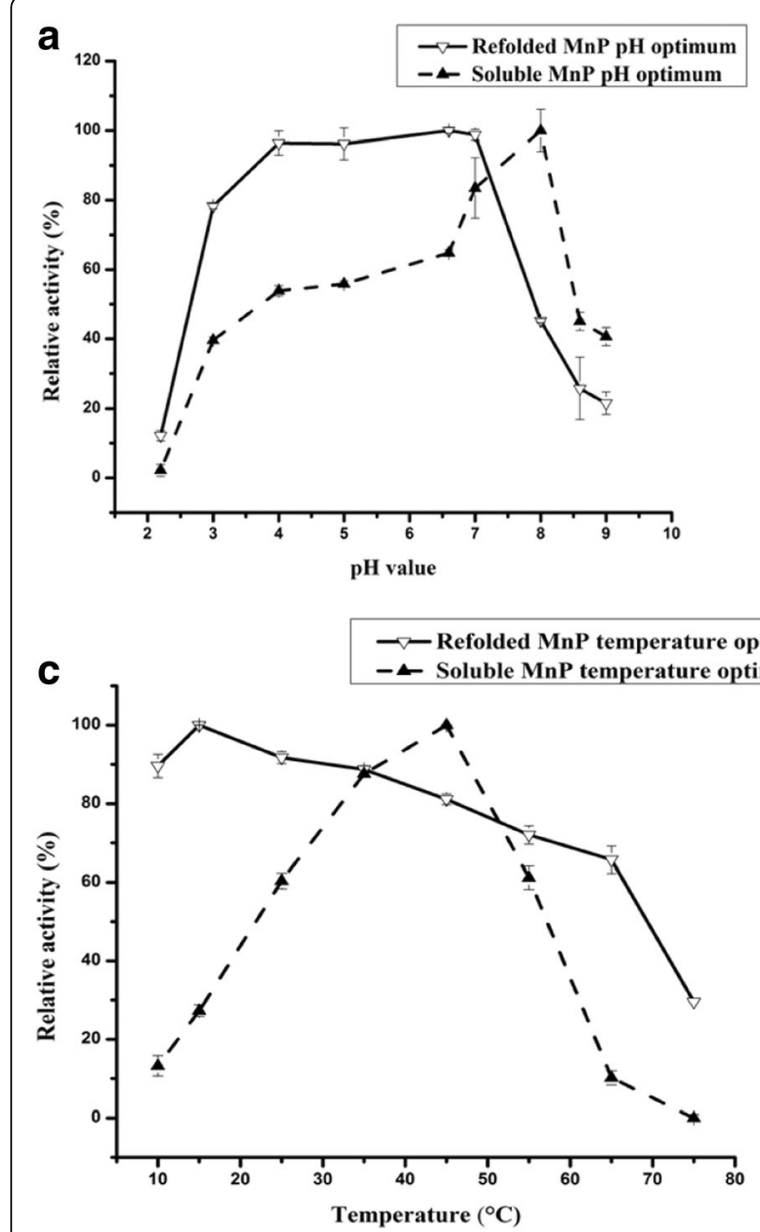
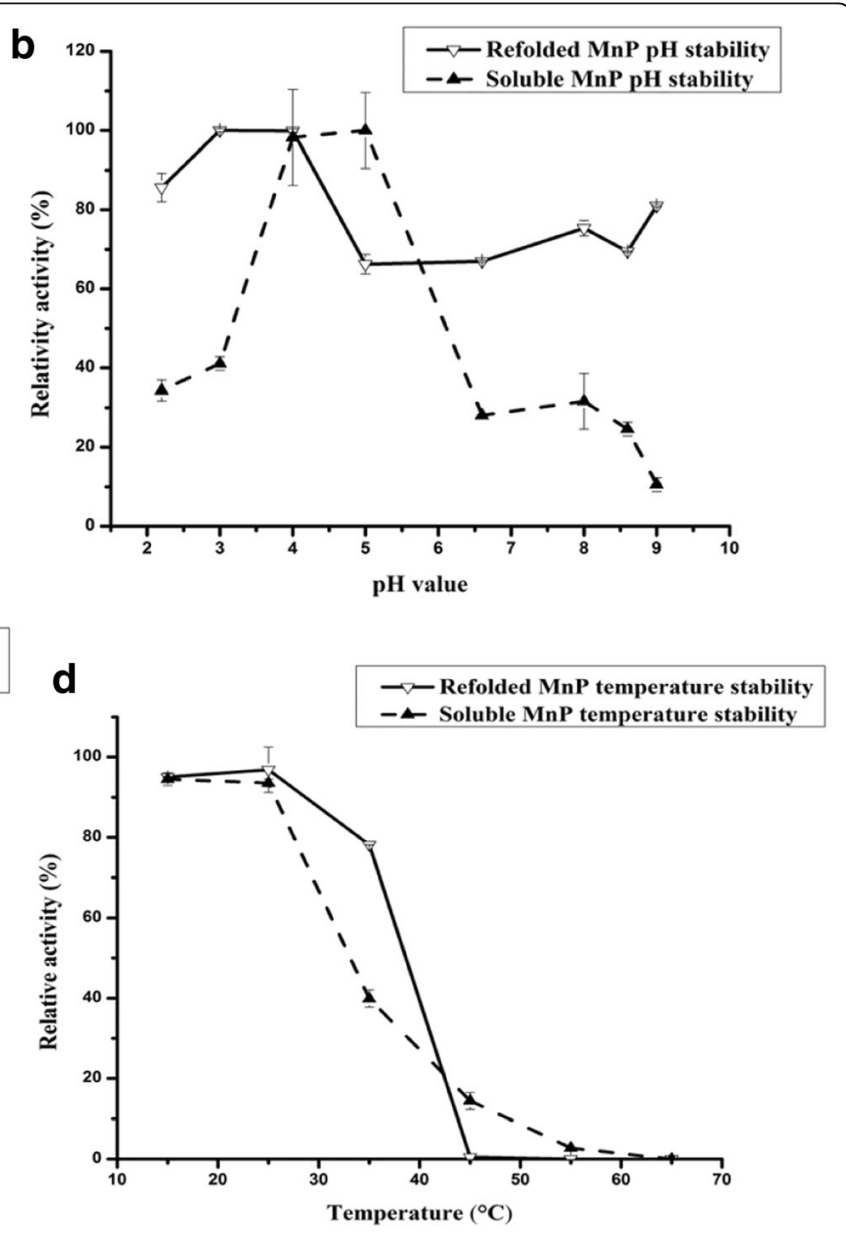

Fig. 2 Effect of $\mathrm{pH}$ and temperature on the activity and stability of refolded and soluble MnP. And MnP activity at the beginning was considered to be $100 \%$. Deviation values are standard deviations based on triplicate determinations. a The pH optimum of refolded and soluble MnP. The MnP activity was determined in the citrate-phosphate buffer, $\mathrm{pH}$ 2.2-8.0 and Tris- $\mathrm{HCl}, \mathrm{pH}$ 8.6-9.0, at $25^{\circ} \mathrm{C}$. $\mathbf{b}$ The $\mathrm{pH}$ stability of refolded and soluble MnP. Refolded and soluble MnP was incubated for $6 \mathrm{~h}$ at $25^{\circ} \mathrm{C}$ in various $\mathrm{pH}$ vaules in citrate-phosphate (2.2-8.0) or Tris-HCl buffer (8.6-9.0). The residual $\mathrm{MnP}$ activity was measured according to the method of MnP activity assay. $\mathbf{c}$ The temperature optimum of refolded and soluble MnP. The enzyme reaction was performed in $0.11 \mathrm{M}$ sodium lactate buffer, $\mathrm{pH} 4.5$ at $10-75^{\circ} \mathrm{C}$. $\mathbf{d}$ The temperature stability of refolded and soluble MnP. Refolded and soluble $\mathrm{MnP}$ were incubated for $6 \mathrm{~h}$ at $15-65^{\circ} \mathrm{C}$. The residual $\mathrm{MnP}$ activity was measured according to the method of MnP activity assay 
Table 7 Substrate specificities of refolded and soluble MnP

\begin{tabular}{|c|c|c|c|c|c|c|c|}
\hline \multirow[t]{2}{*}{ Substrate } & \multirow{2}{*}{$\begin{array}{l}\text { Concentration } \\
(\mathrm{mM})\end{array}$} & \multirow{2}{*}{$\begin{array}{l}\text { Emax } \\
\left(\mathrm{M}^{-1} \mathrm{~cm}^{-1}\right)\end{array}$} & \multirow{2}{*}{$\begin{array}{l}\text { Wavelength } \\
(\mathrm{nm})\end{array}$} & \multicolumn{2}{|c|}{ Refolded $\mathrm{MnP}\left(\mathrm{U} \mathrm{L}^{-1}\right)$} & \multicolumn{2}{|c|}{ Soluble $\mathrm{MnP}\left(\mathrm{U} \mathrm{L}^{-1}\right)$} \\
\hline & & & & $\mathrm{Mn}^{2+}$ present & $\mathrm{Mn}^{2+}$ absent & $\mathrm{Mn}^{2+}$ present & $\mathrm{Mn}^{2+}$ absent \\
\hline ABTS & 1 & 36000 & 420 & $344.93 \pm 0.03$ & $37.73 \pm 0.01$ & $310.0 \pm 0.046$ & $24.4 \pm 0.006$ \\
\hline DMP & 1 & 49600 & 469 & $105.42 \pm 0.04$ & $0.32 \pm 0.001$ & $104.35 \pm 0.05$ & 0 \\
\hline Guaiacol & 1 & 12100 & 456 & $122.31 \pm 0.003$ & $2.27 \pm 0.001$ & $112.40 \pm 0.008$ & 0 \\
\hline
\end{tabular}

conformation modifications between the two enzymes in the protein polypeptide backbone. A low intensity band at $540 \mathrm{~cm}^{-1}$ appeared in the spectrum of soluble MnP indicated the existence of the C-C-S-S-C-C stretching vibrations in trans-gauche-trans arrangements [24], whereas the structure of disulfide bonds was revealed by a weak band near $552 \mathrm{~cm}^{-1}$ in refolded MnP. Furthermore, a band at $759 \mathrm{~cm}^{-1}$ indicated the existence of tryptophan in refolded $\mathrm{MnP}$, while a change occurred in soluble $\mathrm{MnP}$ by shifting the band to $763 \mathrm{~cm}^{-1}$. Also, the phenylalanine bands of refolded MnP were observed at $621 \mathrm{~cm}^{-1}$ and $1203 \mathrm{~cm}^{-1}$. Additionally, the bands at $1380 \mathrm{~cm}^{-1}$ and $1468 \mathrm{~cm}^{-1}$ for soluble $\mathrm{MnP}$, and a band at $1451 \mathrm{~cm}^{-1}$ for refolded $\mathrm{MnP}$ were attributed to the $\mathrm{CH}_{2}$ bending vibrations, showing some changes in protein side chains between the two enzymes.

\section{Size exclusion chromatography and dynamic light scattering analysis}

To further investigate the structural properties of soluble and refolded MnP, SEC and DLS experiments were used to analyze their protein behaviors and status in solution. The DLS distribution patterns of soluble and refolded $\mathrm{MnP}$ were given in Fig. 7 and the corresponding elution profiles were shown in the inset. The data from SEC and DLS were summarized in Table 8. The results revealed some notable differences between the two enzymes. In the case of refolded MnP (Fig. 7a, Table 8), the main peak in FPLC column showed a high specific activity (15.0 U/mg) and a high $\mathrm{Rz}$ (3.1), which corresponded to a monomodal distribution in DLS pattern (Fig. 7a). The hydrodynamic radius of the particle 1 which constituted

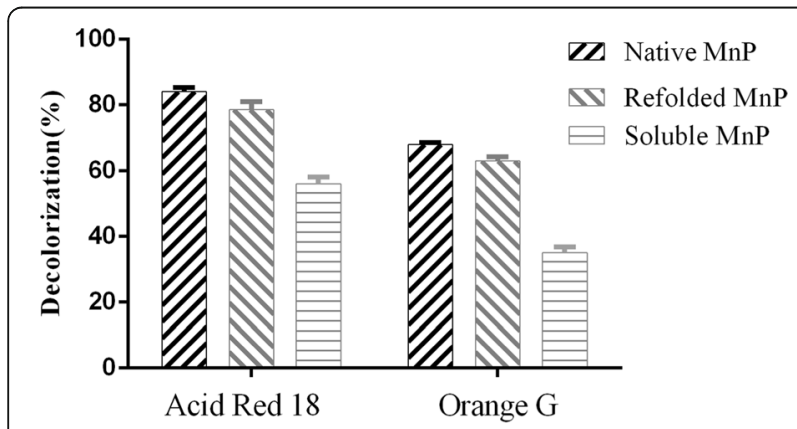

Fig. 3 Acid Red 18 and Orange $G$ decolorization by refolded and soluble MnP
$99.6 \%$ of the protein was $2.9 \pm 0.5 \mathrm{~nm}$, and represented an estimated molecular weight of $42.0 \mathrm{kDa}$. The data is corresponding with the determined $\mathrm{MW}(43.0 \mathrm{kDa})$ of recombinant $\mathrm{MnP}$ on SDS-PAGE, as shown in Fig. 1, and is also consistent with that of native $\mathrm{MnP}$ from Irpex lacteus F17, as reported in the literature [23], as well as the molecular range of the MnP family (38$50 \mathrm{kDa})[25,26]$. Thus, it could be concluded that refolded $\mathrm{MnP}$ was a monomer in solution. In the case of soluble MnP (Fig. 7, Table 8), two prominent peaks of I and II in FPLC column showed low MnP activities and low $\mathrm{Rz}$ values, which corresponded to peak I and peak II of soluble MnP in DLS pattern, respectively (Fig. 7b, c). The DLS results showed that the size distribution of soluble MnP peak I displayed a bimodal distribution with the mass percentage of $70.9 \%$ (particle 1) and $22.3 \%$ (particle 2), respectively (Fig. 7b); particle 1 centered at around $12.9 \mathrm{~nm}$ was dominant and indicated low aggregated oligomers, while particle 2 around $45.3 \mathrm{~nm}$ was comparatively weak and showed large aggregated status. Meanwhile, DLS of soluble MnP also showed a peak II with an average hydrodynamic radius of $4.5 \mathrm{~nm}$ (particle 3 ), which constituteed $99.3 \%$ of the protein and represented an estimated molecular weight of $111.0 \mathrm{kDa}$ (Fig. 7c). This particle 3 probably was related to the formation of protein dimers. Therefore, it could be suggested that the overwhelming majority of soluble $\mathrm{MnP}$ was the oligomeric status in solution under the experimental conditions, different from a single monomeric form of refolded MnP.

\section{Discussion}

Our previous studies indicated that the MnP preprotein from I. lacteus F17 is composed of 359 amino acid residues, including a 26 -amino acid signal peptide and four disulfide bridges essential for the native conformation of the enzyme [22]. A cDNA encoding the mature 333amino acid $\mathrm{MnP}$ protein without the signal sequence was subcloned into pET28a and expressed in E. coli Rosetta (DE3) cells. As expected, this protein formed inclusion bodies and required in vitro refolding to convert it into an active enzyme, as is true for recombinant $\mathrm{MnP}$ from P. chrysosporium [12] and Phlebia radiata [27].

One of the purposes of the present study was to enhance the MnP yield by optimizing the in vitro refolding conditions. Orthogonal design is a good mathematical 

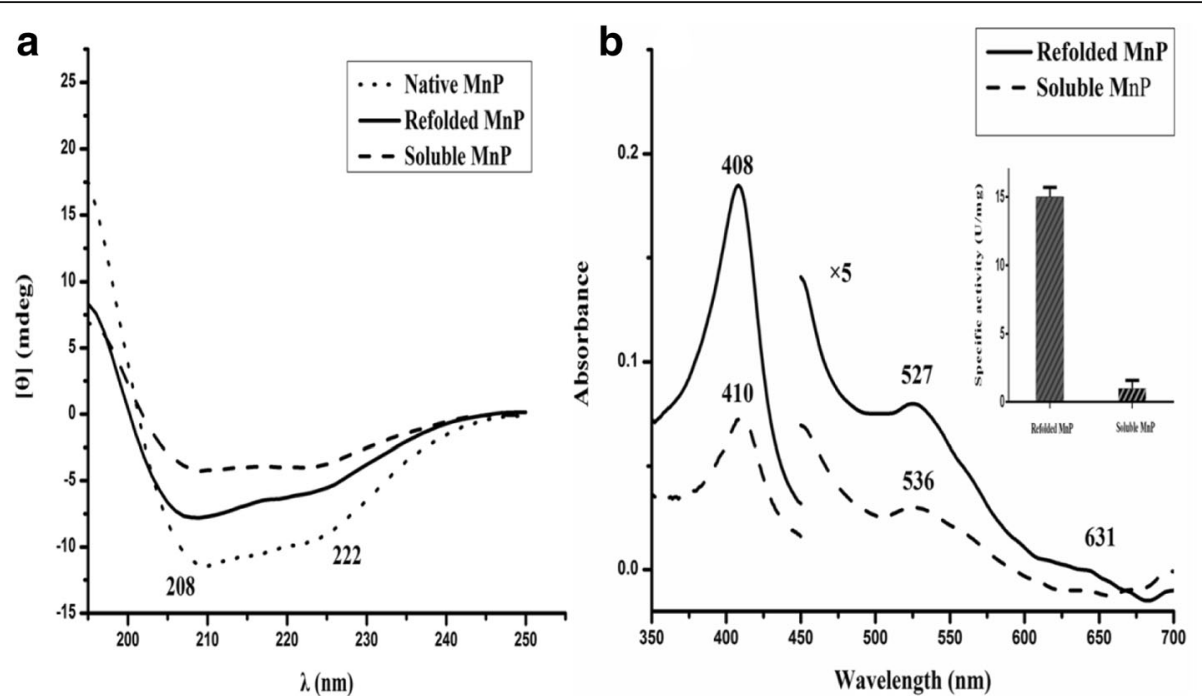

Fig. 4 The far-UV CD and absorbance spectra of refolded and soluble MnP. a The far UV-CD circular dichroism spectra of native, refolded and soluble $\mathrm{MnP}$ at room temperature and $0.1 \mathrm{mg} / \mathrm{ml}$ of protein concentration in $0.15 \mathrm{M}$ phosphate buffer at $\mathrm{pH}$ 6.5. $\mathbf{b}$ Electronic absorption spectra of refolded and soluble MnP at room temperature. The region between 450 and $700 \mathrm{~nm}$ has been expanded ( $\times 5$ absorbance). Enzymatic specific activities are represented in the inset

method used for planning multivariate tests [28]. Its greatest applications have been in healthcare evaluations or comparative effectiveness research [29]. Using an orthogonal design in the present study, the optimal refolding conditions were obtained, and the $\mathrm{MnP}$ yield attained was higher than that obtained in our previous studies, even surpassing those reported for recombinant MnP from P. chrysosporium [12], horseradish peroxidase [30], and lignin peroxidase [31].

Another purpose of the study was to determine whether $\mathrm{MnP}$ could be expressed in a soluble form in E. coli to avoid the tedious process of renaturing inclusion bodies. In

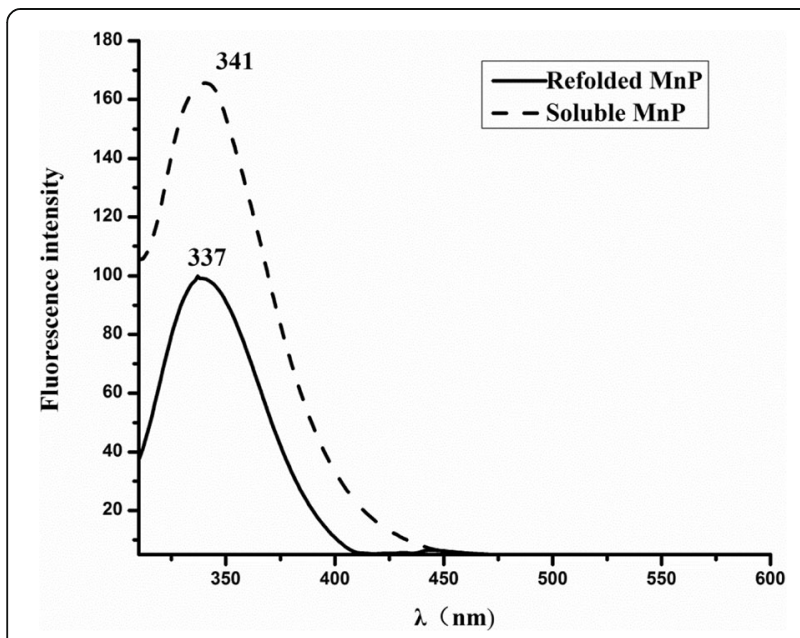

Fig. 5 The emission fluorescence spectra of refolded and soluble $\mathrm{MnP}$. The emission fluorescence spectra of refolded and soluble $\mathrm{MnP}$ at room temperature and $0.1 \mathrm{mg} / \mathrm{ml}$ of protein concentration in the phosphate buffer at $\mathrm{pH} 6.5$ this study, a biologically active form of soluble $\mathrm{MnP}$ was expressed by simultaneously decreasing the expression temperature and adding chemicals to the culture medium. Namely, the recombinant MnP could be expressed as a soluble protein in the presence of four chemicals in the medium, at $16{ }^{\circ} \mathrm{C}$. At low temperature, the rate of protein synthesis slows; thus, proteins have sufficient time to fold, which increases their solubility [32]. Esposito et al. [33] also reported that a lower expression temperature improved the solubility of E. coli-expressed proteins, while a higher expression temperature was conducive to the production of insoluble protein in E. coli Rosetta-gami strains [34].

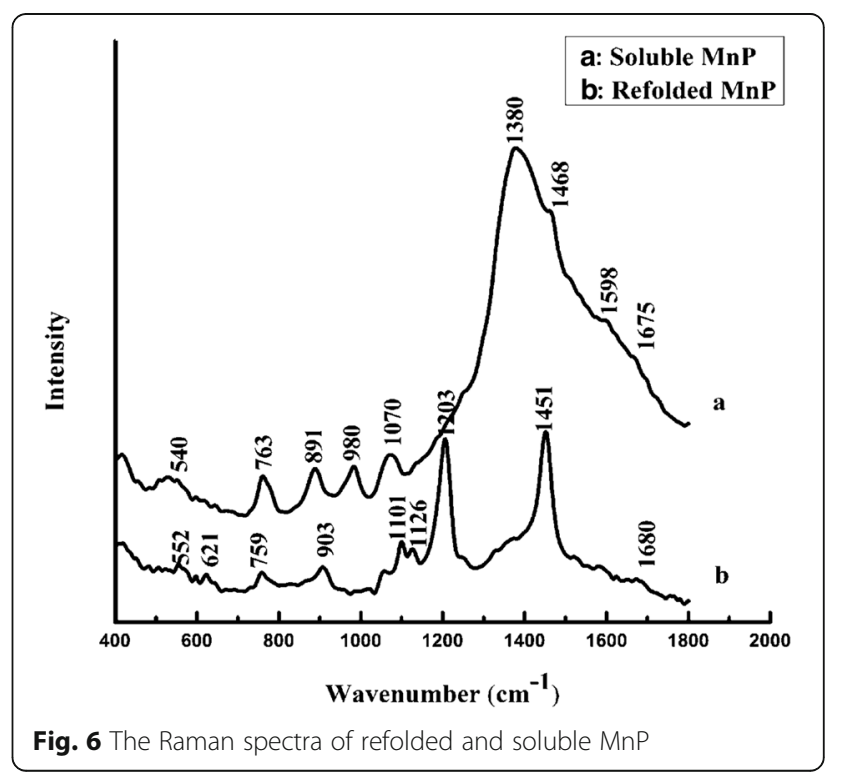



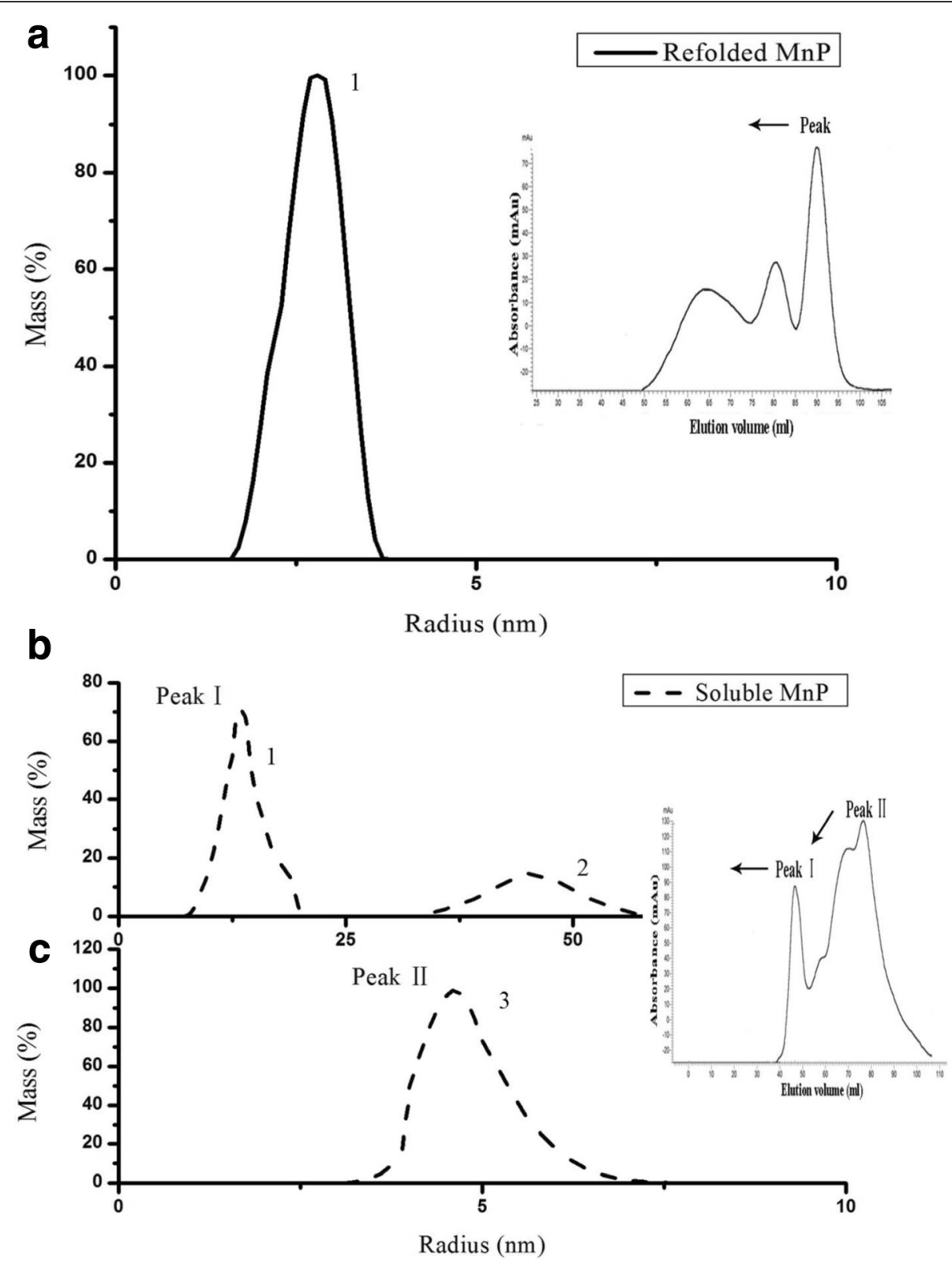

Fig. 7 Protein size analysis of refolded and soluble MnP. a Dynamic light scattering results of refolded MnP. The percentage of the protein mass (\%) was plotted against the hydrodynamic radius $(\mathrm{nm})$. Size exclusion chromatography of refolded MnP purified from Ni-NTA affinity chromatography was shown in the inset. Protein samples were collected after elution with 120 and 200 mM imidazole using 5-ml Ni Sepharose ${ }^{\text {TM }} 6$ Fast Flow. Elution profile of protein was plotted against the absorbance at $280 \mathrm{~nm}$. b \& c Dynamic light scattering results of soluble MnP. The percentage of the protein mass (\%) was plotted against the hydrodynamic radius $(\mathrm{nm})$. Size exclusion chromatography of soluble MnP from Ni-NTA affinity chromatography was shown in the inset

Our results also demonstrated that an expression temperature of $16{ }^{\circ} \mathrm{C}$ could increase the production of soluble MnP, but an expression temperature of $37^{\circ} \mathrm{C}$ could not. In addition, some chemical additives play a useful role in increasing the solubility of recombinant proteins in $E$. coli [19]. Triton X-100 and Tween- 80 are surfactants that can change the osmotic pressure in bacterial membranes [35]. Moreover, Triton X-100 supplementation in culture medium can hinder the formation of inclusion bodies in $E$. coli, and facilitate the secretion of recombinant proteins to the periplasmic space or culture medium [36]. Glycerol is commonly used as a protective agent to increase protein stability, as it is able to decrease the surface tension of water and increase viscosity [37]. An optimum glycerol concentration can stabilize protein structures, even at high protein concentrations. Ethanol has also been shown to increase the fraction of soluble protein [38]. Steczko et al. [39] reported that adding $3 \%$ ethanol dramatically 
Table 8 Summary of the data from DLS and FPLC for refolded and soluble MnP

\begin{tabular}{|c|c|c|c|c|c|}
\hline Size distribution & Radius (nm) & Molecular weight (kDa) & Mass (\%) & Specific activity (U/mg) & Rz (Soret/280) \\
\hline \multicolumn{6}{|l|}{ refolded $\mathrm{MnP}$} \\
\hline Particle 1 & $2.9 \pm 0.5$ & 42.0 & 99.6 & $15.0 \pm 2.1$ & $3.1 \pm 0.6$ \\
\hline \multicolumn{6}{|l|}{ soluble MnP peak I } \\
\hline Particle 1 & $12.9 \pm 0.7$ & 1314.0 & 70.9 & $0.6 \pm 1.5$ & $1.0 \pm 0.3$ \\
\hline Particle 2 & $45.3 \pm 1.4$ & 25199.0 & 22.3 & & \\
\hline \multicolumn{6}{|c|}{ soluble MnP peak II } \\
\hline Particle 3 & $4.5 \pm 0.8$ & 111.0 & 99.3 & $0.2 \pm 0.8$ & $0.3 \pm 1.1$ \\
\hline
\end{tabular}

"Particle 1" of refolded MnP was presented in Fig. 7a; "Particle 1", "Particle 2" and "Particle 3" of soluble MnP were presented in Fig. 7b and Fig. 7c. The results of hydrodynamic radius, specific activity and $\mathrm{Rz}$ were given as the mean \pm standard deviation, calculated from at least three repetitions

increased the amount of soluble, active soybean seed lipoxygenase L-1. Using an orthogonal design, we determined the optimized combination of Triton X-100, Tween-80, glycerol, and ethanol, which resulted in the expression of soluble MnP in E. coli Rosetta (DE3) cells. Thus, it was also confirmed that these solutes did not impair cell metabolism and that they were compatible solutes [40]. MnP activity was detected in the cell lysates after hemin and $\mathrm{Ca}^{2+}$ supplementation at $\mathrm{pH}$ 8.0. However, recombinant $\mathrm{MnP}$ was not secreted into the culture medium, as determined by SDS-PAGE and enzyme activity assays, in our study.

As a result, soluble MnP was successfully induced and expressed in E. coli when grown in the presence of the four additives at $16{ }^{\circ} \mathrm{C}$, as opposed to forming inclusion bodies. These additives could be used as agents to increase the yield of soluble proteins at lower temperatures. Although the concrete mechanism underlying this phenomenon is unclear, a case like this has been observed previously. Bacterial cytoplasm is a rather reducing environment, it generally inhibits the formation of disulfide bonds [41], while the periplasmic space provides an oxidative environment that facilitates proper protein folding [42]. Lee and Choi [36] described the secretory and extracellular production of recombinant proteins, which were exported to periplasm space or culture medium, using protein secretion systems in E. coli. Prasad et al. [19] suggested that chemical chaperones, such as sorbitol and arginine, increased the solubility of recombinant proteins. Yang et al. [43] reported that culturing conditions had effects on the production of heterologous proteins in E. coli. However, in the present study, the detailed information to reveal which pathways take part in the formation of soluble MnP have not been determined and need to be further investigated.

It is worth mentioning that hemin is crucial to activate soluble MnP. Heme is a non-covalently bound prosthetic group in MnP; hence, adding exogenous hemin to the cell lysates is necessary to yield an active holoenzyme. Additionally, $\mathrm{Ca}^{2+}$ supplementation is crucial to achieve the correct conformation, as well as the stability, of recombinant $\mathrm{MnP}$ [44, 45], because both $\mathrm{Ca}^{2+}$ ions are easily lost in a thermal or alkaline environment $[6,46]$.
Compared with refolded $\mathrm{MnP}$, soluble $\mathrm{MnP}$ showed low catalytic efficiencies $\left(k_{c a t} / K_{m}\right)$ for $\mathrm{Mn}^{2+}$ and $\mathrm{H}_{2} \mathrm{O}_{2}$ substrates and was more susceptible to $\mathrm{H}_{2} \mathrm{O}_{2}$. The kinetic parameters are in agreement with those obtained from the spectroscopic characterizations. Additionally, both of the soluble and refolded MnP exhibited a broad range of substrate specificities in the presence of $\mathrm{Mn}^{2+}$. Interestingly, soluble $\mathrm{MnP}$ had an optimum $\mathrm{pH}$ of 8.0 and an optimum temperature of $45{ }^{\circ} \mathrm{C}$, which are obviously different from those of refolded $\mathrm{MnP}(\mathrm{pH} 6.5$ and $15{ }^{\circ} \mathrm{C}$, respectively) and most of the reported fungal MnPs [47-49]. Furthermore, the two enzymes had the ability to decolorize the azo dyes Acid Red 18 and Orange $\mathrm{G}$, but the decolorization efficiency of soluble $\mathrm{MnP}$ was lower than that of refolded MnP.

Experiments of $\mathrm{CD}$ and UV-VIS absorption spectra showed certain differences in the secondary structures, Soret peaks and other bands between soluble and refolded MnP (Fig. 4a and b). Compared with refolded $\mathrm{MnP}$, soluble MnP showed the Soret peak height reduced by about $40 \%$ and red-shifted $2 \mathrm{~nm}$, Q band reduced by about $37 \%$ and red-shifted $9 \mathrm{~nm}$, as well as an inconspicuous CT band $(631 \mathrm{~nm})$. A characteristic CT band at $631 \mathrm{~nm}$ was observed in the spectrum of refolded $\mathrm{MnP}$, indicating a high-spin configuration of the protein, because the wavelength of the region between 600 and $650 \mathrm{~nm}$ is sensitive to changes in the heme microenvironment [50, 51]. This band, assigned to a charge transfer transition from the porphyrin to the iron, was typical of a high-spin heme $\mathrm{Fe}^{3+}$ states [51]. The specific activities and $R_{Z}$ values demonstrated that soluble $\mathrm{MnP}$ was less active than refolded $\mathrm{MnP}$. The $\mathrm{CD}$ spectra analyses indicated that refolded $\mathrm{MnP}$ was more closer to native $\mathrm{MnP}$, in terms of its $\alpha$-helix and $\beta$-sheet contents, than soluble MnP. Thus, it appears that the optimized in vitro refolding conditions helped MnP to refold into its native conformation. Nevertheless, soluble $\mathrm{MnP}$ exhibited a lower $\alpha$-helix content than refolded $\mathrm{MnP}$, while its $\beta$-sheet content was higher, indicating that the two structures differed. Hence, the lower specific activity of soluble $\mathrm{MnP}$ could be ascribed to a 
change in protein structure, and the lower $R_{Z}$ value could result from an insufficient incorporation of exogenous hemin. Fluorescence spectra also showed the differences in protein conformation. Compared with refolded $\mathrm{MnP}$, soluble $\mathrm{MnP}$ exhibited a 4-nm red shift, implying that the tryptophan residue in the protein was more exposed to a hydrophilic environment (MnP contains one tryptophan residue, GenBank accession no. AGO86670.2). Raman spectroscopy is also an efficient technique that is capable of investigating protein molecular structures, good for solid samples as well as aqueous solutions [24]. Recently, Raman spectra have been used for the analysis of different structures of various proteins $[24,52,53]$. Therefore, in the present study, comparisons of major Raman scattering bands were made between soluble and refolded MnP. The results indicated that both enzymes have different Raman characteristic bands, which reflected their structural differences in protein backbone conformations and protein side chains. Moreover, the results from SEC and DLS also supported these findings. The elution profile of refolded $\mathrm{MnP}$ produced a main fraction, corresponding to monomeric protein with an $\mathrm{Rz}$ value greater than 3 . This data $(\mathrm{Rz}>3)$ is a significant characteristic of highly purified $\mathrm{MnP}$ and almost identical to that of the native fungal $\mathrm{MnP}$ [12]. Further, we confirmed the monomeric nature of the native $\mathrm{MnP}$ from Irpex lacteus F17 in solution by DLS studies (Additional file 1: Figure S1). Therefore, it was obvious that the quality of refolded MnP was good and the optimized refolding conditions in vitro were achieved. However, we noticed that soluble MnP showed aggregate behavior through dimerization and polymerization in solution. As such, it can be considered that a decrease in enzymatic activity and $\mathrm{Rz}$ value could be ascribed to the aggregate formation of soluble MnP. In addition, the DLS results provided reasonable explanation for their differences of CD, fluorescence and Raman spectra between soluble and refolded MnP. Nevertheless, the mechanism of such aggregate formation for soluble MnP still needs further study. Chihi et al. [54] demonstrated that the hydrophobic interactions and the formation of new disulfide bridges resulted in soluble protein aggregates; while, Wang et al. [55] emphasized the importance of the hydrophobic interaction in promoting the protein aggregate, as compared with disulfide bonds. Therefore, we will shed light on the intriguing mechanism of polymerization for soluble MnP in the future.

Although secretory production of soluble MnP in $E$. coli did not result in an ideal enzyme activity, it has some advantages over inclusion bodies [36]. Furthermore, several strategies for the efficient secretory production of recombinant proteins in $E$. coli have been explored $[16,19,34]$. To our knowledge, ours is the first report of soluble $\mathrm{MnP}$ expression in E. coli, and it provides an optional solution for obtaining biologically active forms of recombinant proteins.

\section{Conclusions}

In summary, using a one-factor-at-a-time method and an orthogonal design, the optimal conditions for the production of refolded and soluble $\mathrm{MnP}$ were obtained. The refolded protein yield was improved, and the specific activity of refolded $\mathrm{MnP}$ increased by approximately twofold. Soluble MnP was also successfully induced and expressed in E. coli, but it was less active than refolded MnP. This phenomenon was confirmed by biochemical and spectroscopic characterizations, as well as their different abilities to decolorize azo dyes. Based on SEC and DLS analyses, refolded MnP was a monomer in solution, while soluble $\mathrm{MnP}$ behaved as the protein aggregates. Further studies to improve the activity of soluble $\mathrm{MnP}$ and clarify its aggregation mechanism are required and are currently in progress in our laboratory.

\section{Methods \\ Chemicals}

Lysozyme, glutathione (GSSG), dithiothreitol (DTT), $\mathrm{H}_{2} \mathrm{O}_{2}$, 2,6-dimethoxyphenol (DMP), 2,2'-azino-bis(3-ethylbenzothiazoline-6-sulfonic acid) (ABTS), phenylmethanesulfonyl fluoride (PMSF), and isopropyl- $\beta$-D-thiogalactopyranoside (IPTG) were purchased from Sigma-Aldrich (St. Louis, MO, USA). Triton X-100, Tween-80, ethanol, and other chemicals were obtained from Macklin (Shanghai, China) and were of analytical grade.

\section{Host strain and expression vector}

The E. coli strain Rosetta (DE3) was used as a host for recombinant $\mathrm{MnP}$ production. The mature $\mathrm{MnP}$ cDNA sequence, named imnp, was amplified by polymerase chain reaction using the genomic DNA of I. lacteus F17 as a template [22]. The imnp cDNA was excised with $X h o I$ and NcoI, and inserted into the expression vector $\mathrm{pET} 28 \mathrm{a}(+)$. The resulting construct (named pET28aimnp) was used to transform E. coli.

\section{MnP activity assay}

$\mathrm{MnP}$ activity was determined by the oxidation of $\mathrm{Mn}^{2+}$ to $\mathrm{Mn}^{3+}$ at $25{ }^{\circ} \mathrm{C}$ and $240 \mathrm{~nm}\left(\varepsilon=6500 \mathrm{M}^{-1} \mathrm{~cm}^{-1}\right)$. Incubation mixtures $(1 \mathrm{ml})$ contained $0.11 \mathrm{M}$ sodium lactate buffer (pH 4.5), $1 \mathrm{mM} \mathrm{MnSO} 4,0.1 \mathrm{mM} \mathrm{H}_{2} \mathrm{O}_{2}$, and $25 \mu \mathrm{l}$ of enzyme sample. One unit (U) of MnP activity was defined as the amount of enzyme needed to oxidize $1 \mu \mathrm{mol}$ of $\mathrm{Mn}^{2+}$ per min.

Additionally, when screening parameters that influence enzyme activity, MnP activity was also estimated using the naked eye to detect a color change based on the oxidation of 2,6-dimethoxyphenol (2,6-DMP) by 
$\mathrm{MnP}$, which forms a quinone dimer at $469 \mathrm{~nm}$. The DMP oxidation assay was conducted at $30{ }^{\circ} \mathrm{C}$ in $0.1 \mathrm{M}$ sodium lactate buffer ( $\mathrm{pH} 4.5$ ) containing $1 \mathrm{mM} \mathrm{MnSO}_{4}$, $0.1 \mathrm{mM} \mathrm{H}_{2} \mathrm{O}_{2}, 1 \mathrm{mM}$ DMP, and $25 \mu \mathrm{l}$ of MnP. MnP activity assay was performed in triplicate. All the data are the mean values of triplicates.

\section{Expression of $\mathrm{MnP}$ as inclusion bodies}

E. coli Rosetta (DE3) harboring the recombinant vector pET28a-imnp was grown at $37^{\circ} \mathrm{C}$, and recombinant $\mathrm{MnP}$ was expressed in the form of inclusion bodies. In vitro refolding was performed according to the method of Chen et al. [22]. The optimal refolding conditions were further studied in small-scale experiments. To begin with, a onefactor-at-a-time method was used to screen influencing factors and corresponding levels on $\mathrm{MnP}$ refolding. In this set of experiments, parameter ranges in the refolding solutions were set at: urea (0.1-4.0 M), GSSG (0-5.0 mM), glycerol (0-25\%), $\mathrm{MnSO}_{4}(0-5.0 \mathrm{mM}), \mathrm{KCl}(0-100 \mathrm{mM}), \mathrm{CaCl}_{2}(0-$ $300 \mathrm{mM})$, and hemin $(0-500 \mu \mathrm{M})$, as well as $\mathrm{pH}(7.0-9.5)$ and incubation time $(0-110 \mathrm{~h})$. Factors exhibiting significant effects were selected out by observing DMP oxidation in 48-deep well plates. To achieve a higher refolding efficiency and test mutual interactions of those factors obtained by the single-factor experiment, an orthogonal experimental design was used to determine the optimum combination of significant factors and their concentrations. The refolding efficiency was estimated by analyzing the specific $\mathrm{Mn}^{2+}$ oxidizing activity of the dialyzed refolded MnP.

\section{Expression of soluble MnP}

E. coli cells harboring pET28a-imnp were grown at $37{ }^{\circ} \mathrm{C}$ in Luria-Bertani broth containing $50 \mu \mathrm{g} / \mathrm{ml}$ kanamycin sulfate and $34 \mu \mathrm{g} / \mathrm{ml}$ chloramphenicol, as described by Chen et al. [22]. When the optical density at $600 \mathrm{~nm}$ reached 0.5-0.6, 0.3 mM IPTG was added to the cultures. Simultaneously, different concentrations of chemicals were also added to the culture medium. Then, the growth temperature was lowered from $37{ }^{\circ} \mathrm{C}$ to $16{ }^{\circ} \mathrm{C}$, and the cultures were incubated for $16 \mathrm{~h}$, with shaking at $120 \mathrm{rpm}$, to induce the expression of soluble MnP. Bacterial pellets were obtained by centrifugation at $4{ }^{\circ} \mathrm{C}$ at $7800 \mathrm{~g}$ for $10 \mathrm{~min}$, and they were resuspended in lysis buffer (containing $5 \mathrm{mM}$ imidazole, $0.02 \mathrm{mM}$ PMSF, $0.5 \mathrm{M} \mathrm{NaCl}$, $20 \mathrm{mM}$ Tris, and $\mathrm{pH} 8.0$ ) in $1 / 10$ of the original culture volume. Then bacteria were lysed by sonication for $30 \mathrm{~min}$. After that, the lysed cells were centrifuged at $4{ }^{\circ} \mathrm{C}$ at $10,000 \mathrm{~g}$ for $30 \mathrm{~min}$, and then, $10 \mu \mathrm{M}$ hemin and $25 \mathrm{mM} \mathrm{CaCl}_{2}$ were added to the supernatant, which was stored at $4{ }^{\circ} \mathrm{C}$ for $6 \mathrm{~h}$. Finally, the solution containing soluble $\mathrm{MnP}$ was centrifuged at $4{ }^{\circ} \mathrm{C}$ for $30 \mathrm{~min}$ to remove any excess hemin.

Like the optimization design for the refolding of inclusion bodies, several chemical additives (Triton X-100,
Tween-80, ethanol, glycerol, sorbitol, L-proline, and glycine), as well as their concentrations, were tested using the one-factor-at-a-time method to achieve the soluble expression of MnP. Factors exhibiting significant effects were selected by observing DMP oxidation in 48-deep well plates. Subsequently, the optimum combination of significant factors, as well as their concentrations, was further optimized by an orthogonal experimental design to obtain greater soluble MnP expression. The optimum factor combination was estimated by analyzing the specific $\mathrm{Mn}^{2+}$ oxidizing activity of $\mathrm{MnP}$ after adding exogenous hemin and $\mathrm{Ca}^{2+}$ to the cell lysates.

\section{Purification of recombinant MnP}

Recombinant MnP was purified using a $\mathrm{Ni}^{2+}$-affinity column (Sangon Biotech, Shanghai, China) according to the manufacturer's instructions. Sodium dodecyl sulfatepolyacrylamide gel electrophoresis (SDS-PAGE) was conducted using a $12 \%$ Tris- $\mathrm{HCl}$ separation gel and a $5 \%$ Tris- $\mathrm{HCl}$ staking gel, followed by staining with Coomassie Brilliant Blue R-250.

\section{Biochemical characterization of $\mathrm{MnP}$ Determination of kinetic parameters of soluble and refolded $M n P$}

The $K_{m}$ and $k_{c a t}$ for $\mathrm{Mn}^{2+}$ were determined by the hyperbolic, non-linear least squares method at varying $\mathrm{MnSO}_{4}$ concentrations $(0.025-1.0 \mathrm{mM})$ in the presence of $0.1 \mathrm{mM} \mathrm{H}_{2} \mathrm{O}_{2}$. The $K_{m}$ and $k_{\text {cat }}$ for $\mathrm{H}_{2} \mathrm{O}_{2}$ were determined at varying $\mathrm{H}_{2} \mathrm{O}_{2}$ concentrations $(0.01-0.15 \mathrm{mM})$ in the presence of $1 \mathrm{mM} \mathrm{MnSO}_{4}$. The reactions were conducted at $25^{\circ} \mathrm{C}$ in $0.11 \mathrm{M}$ of sodium lactate buffer $(\mathrm{pH} 4.5)$.

\section{Effect of $\mathrm{pH}$ and temperature on the activity and stability of $\mathrm{MnP}$}

The optimum $\mathrm{pH}$ for activites of soluble and refolded $\mathrm{MnP}$ was evaluated at $25^{\circ} \mathrm{C}$ in $0.11 \mathrm{M}$ citrate-phosphate buffer (pH 2.2-8.0) or Tris- $\mathrm{HCl}$ buffer ( $\mathrm{pH} 8.6-9.0)$. $\mathrm{pH}$ stability was determined at $25{ }^{\circ} \mathrm{C}$ by incubating the enzyme at different $\mathrm{pH}$ values (2.2-9.0) for $6 \mathrm{~h}$. The residual MnP activity was measured according to the method used for the MnP activity assay.

The optimum temperature for $\mathrm{MnP}$ activity was measured from 10 to $75{ }^{\circ} \mathrm{C}$ in appropriate increments in $0.11 \mathrm{M}$ sodium lactate buffer $(\mathrm{pH} 4.5)$. To evaluate the thermal stability of $\mathrm{MnP}$, the enzyme was incubated at temperatures ranging from 15 to $65{ }^{\circ} \mathrm{C}$ in appropriate increments for $6 \mathrm{~h}$. The residual MnP activity was measured according to the method used for the MnP activity assay.

\section{Substrate specificity}

The oxidation of guaiacol $\left(\varepsilon=12,100 \mathrm{M}^{-1} \mathrm{~cm}^{-1}\right)$, DMP $\left(\varepsilon=49,600 \mathrm{M}^{-1} \mathrm{~cm}^{-1}\right)$ and ABTS $\left(\varepsilon=36,000 \mathrm{M}^{-1} \mathrm{~cm}^{-1}\right)$ was measured at 456,469 , and $420 \mathrm{~nm}$, respectively, to 
estimate the substrate specificities of soluble and refolded MnP. The reaction mixtures contained $0.11 \mathrm{M}$

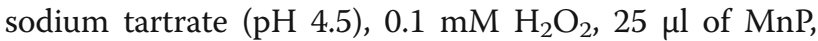
with or without $1 \mathrm{mM} \mathrm{Mn}^{2+}$, in a total volume of $1 \mathrm{ml}$. The $\mathrm{Mn}^{2+}$ oxidizing activity of both soluble and refolded $\mathrm{MnP}$ was $530 \mathrm{U} / \mathrm{L}$.

\section{Decolorization of Acid Red 18 and Orange $\mathrm{G}$ by recombinant $\mathrm{MnP}$}

Dye decolorization was measured spectrophotometrically at 506 and $478 \mathrm{~nm}$ (WFV UV-2100 spectrophotometer, UNICO, Shanghai, China), which are the maximum visible absorbances of Acid Red 18 and Orange G, respectively.

The decolorization reaction system contained sodium tartrate $(0.11 \mathrm{M}, \mathrm{pH} 4.0), \mathrm{MnSO}_{4}(1.25 \mathrm{mM}), \mathrm{H}_{2} \mathrm{O}_{2}$ $(0.15 \mathrm{mM}))$, dye $(50 \mathrm{mg} / \mathrm{L})$, and $\mathrm{MnP}(100 \mathrm{U} / \mathrm{L})$ in a total volume of $1 \mathrm{ml}$. The reaction was initiated by the addition of $\mathrm{H}_{2} \mathrm{O}_{2}$. Control samples, without enzyme, were performed in parallel under identical conditions.

The decolorization efficiency was obtained from the following equation:

$$
\text { Decolorization }(\%)=\frac{A_{0}-A_{t}}{A_{0}} \times 100 \%
$$

where $A_{0}$ is the initial absorbance at $506 \mathrm{~nm}$ for Acid Red 18 or at $478 \mathrm{~nm}$ for Orange G, and $A_{t}$ refers to the absorbance at $506 \mathrm{~nm}$ or $478 \mathrm{~nm}$ at reaction time $t$. The data are presented as the mean values of triplicate experiments.

\section{Spectroscopic characterization of $\mathrm{MnP}$}

Far-UV circular dichroism (CD) spectra and UV-VIS spectra The CD measurements were implemented with a MOS500 CD spectrometer (Bio-Logic, Grenoble, France), with a 1-mm light path cell, at room temperature. The CD spectra were recorded using a 2-mm bandwidth in the far-UV region $(190-250 \mathrm{~nm})$. The protein concentration was $0.1 \mathrm{mg} / \mathrm{ml}$ in $0.15 \mathrm{M}$ phosphate buffer, $\mathrm{pH}$ 6.5. The UV-VIS spectra were obtained in the 200$700 \mathrm{~nm}$ region at room temperature using a DU $730 \mathrm{UV}$ spectrophotometer (Beckman Coulter, Brea, CA, USA), and the protein concentration was $0.5 \mathrm{mg} / \mathrm{ml}$ in $0.15 \mathrm{M}$ phosphate buffer, pH 6.5 .

\section{Fluorescence spectroscopy}

All fluorescence spectra of enzymes were obtained at room temperature using an F-4500 FL spectrophotometer (Hitachi, Tokyo, Japan) using a cuvette with a 10$\mathrm{mm}$ path length. Excitation and emission bandwidths were set at $5 \mathrm{~nm}$. Fluorescence measurements were performed at a protein concentration of $0.1 \mathrm{mg} / \mathrm{ml}$.

\section{Raman spectra}

After protein purification, enzyme solution was dried under vacuum freezing condition for $24 \mathrm{~h}$ to produce the solid powder samples. Protein samples were prepared and stored at $-20{ }^{\circ} \mathrm{C}$. The Raman spectra of soluble and refolded $\mathrm{MnP}$ were obtained in the $400 \mathrm{~cm}^{-1}$ to $1800 \mathrm{~cm}^{-1}$ at room temperature using a InVla-Reflex instrument (Renishaw, London, England) equipped with excitation from the $785 \mathrm{~nm}$ line of a semiconductor laser and a charge-coupled-device (CCD) array detector. The laser was focused through an Olympus 50x objective lens on the solid protein samples. The laser power was $8.4 \mathrm{~mW}$, and the resolution was $0.48 \mathrm{~cm}^{-1}$. An acquisition time of 30 s was used.

\section{Size exclusion chromatography and dynamic light scattering}

After being purified using Ni-NTA affinity chromatography, protein samples were further purified by a HiLoad ${ }^{\mathrm{m}}$ 16/60 superdex 200 gel filtration column (10-600 kDa, GE health care, USA) equilibrated with protein buffer $(20 \mathrm{mM}$ Tris- $\mathrm{HCl}$ ( $\mathrm{pH} 8.0), 200 \mathrm{mM} \mathrm{NaCl}$ ). Elution was performed with the same buffer at a flow rate of $1 \mathrm{ml} / \mathrm{min}$. Absorbance was monitored at $280 \mathrm{~nm}$. Fractions containing $\mathrm{MnP}$ activity peak were pooled and kept at $4{ }^{\circ} \mathrm{C}$ to be used for dynamic light scattering studies. Dynamic light scattering (DLS) spectra were obtained at room temperature using an Dynapro-MS800 instrument (Wyatt, Santa Barbara, CA, USA) and high precision cell made of quartz suprasil with $1.5 \mathrm{~mm}$ path length. The protein concentration was diluted to a final concentration of $0.1 \mathrm{mg} / \mathrm{ml}$ with $20 \mathrm{mM}$ Tris$\mathrm{HCl}(\mathrm{pH} \mathrm{8.0)}$ and $200 \mathrm{mM} \mathrm{NaCl}$. Before measurement, all samples were centrifuged at $4{ }^{\circ} \mathrm{C}$ at $10,000 \mathrm{~g}$ for $10 \mathrm{~min}$. The radius and estimated molecular weight were provided by the Dynamics software.

\section{Additional files}

\section{Additional file 1: Figure S1. Protein size analysis of native MnP.} (DOCX 267 kb)

Additional file 2: Raw data used for the production of Fig. 6 and Fig. 7. (XLSX 67 kb)

\section{Abbreviations}

ABTS: 2,2'-azino-bis(3-ethylbenzothiazoline-6-sulfonic acid); CD: Circular dichroism; DLS: Dynamic light scattering; DMP: 2,6-dimethoxyphenol; DTT: Dithiothreitol; E. coli: Escherichia coli; FPLC: Fast protein liquid chromatography; GSSG: Glutathione; $\mathrm{H}_{2} \mathrm{O}_{2}$ : Hydrogen peroxide; I. lacteus F17: Irpex lacteus F17; IPTG: Isopropyl- $\beta$-D-thiogalactopyranoside; MnP: Manganese peroxidase; PMSF: Phenylmethanesulfonyl fluoride; Rz: Reinheitszahl; SDS-PAGE: Sodium dodecyl sulfate-polyacrylamide gel electrophoresis; SEC: Size exclusion chromatography

Acknowledgements

We thank Chao He for her help to the dynamic light scattering experiment. 


\section{Funding}

This work was supported by the National Natural Science Foundation of China (31570102, 31070109) and the College Students' Innovation and Entrepreneurship Training Project of Anhui University.

\section{Availability of data and materials}

All the data supporting our conclusions are included within the manuscript and its Additional files. The datasets used for the production of Fig. 6 and Fig. 7 could be found in the Additional file 2 "Raw Data.xIsx".

\section{Authors' contributions}

WN carried out all expression, purification and characterization analyses of recombinant $\mathrm{MnP}$, participated in the design of the experiments and drafted the manuscript. RK participated in the optimal experiment for the expression of soluble MnP and performed the data analysis. JR conceived of the study, and participated in its design and helped to revise the manuscript. CWT carried out the cloning and transforming experiments. SRR participated in enzymatic assays. All authors read and approved the final manuscript.

\section{Competing interests}

I confirm that I have read BioMed Central's guidance on competing interests and we declare that we have no competing interests.

\section{Consent for publication}

This work did not contain any individual persons data.

\section{Ethics approval}

This work did not report on or involve the use of any animal or human data or tissue.

Received: 5 August 2016 Accepted: 23 November 2016 Published online: 01 December 2016

\section{References}

1. Hammel KE, Kalyanaraman B, Kirk TK. Substrate free radicals are intermediates in ligninase catalysis. Proc Natl Acad Sci. 1986;83(11):3708-12.

2. Michel FC, Dass SB, Grulke EA, Reddy CA. Role of manganese peroxidases and lignin peroxidases of Phanerochaete chrysosporium in the decolorization of kraft bleach plant effluent. Appl Environ Microbiol. 1991;57(8):2368-75.

3. Maijala P, Kleen M, Westin C, Poppius-Levlin K, Herranen K, Lehto JH, Reponen $\mathrm{P}$, Mäentausta $\mathrm{O}$, Mettälä A, Hatakka A. Biomechanical pulping of softwood with enzymes and white-rot fungus Physisporinus rivulosus. Enzyme Microb Technol. 2008;43:169-77.

4. Sundaramoorthy M, Kishi K, Gold MH, Poulos TL. Preliminary crystallographic analysis of manganese peroxidase from Phanerochaete chrysosporium. J Mol Biol. 1994:238:845-8.

5. Fernández-Fueyo E, Ruiz-Dueñas FJ, Martínez MJ, Romero A, Hammel KE, Medrano FJ, Martínez AT. Ligninolytic peroxidase genes in the oyster mushroom genome: heterologous expression, molecular structure, catalytic and stability properties, and lignin-degrading ability. Biotechnol Biofuels. 2014;7:2.

6. Martínez AT. Molecular biology and structure-function of lignin-degrading heme peroxidases. Enzyme Microb Tech. 2002;30:425-44.

7. Saroj S, Agarwal P, Swati D, Singh RP. Manganese peroxidases: molecula diversity, heterologous expression, and applications. Advances in Enzyme Biotechnology. 2013:67-87.

8. Singh D, Chen S. The white-rot fungus Phanerochaete chrysosporium: conditions for production of lignin-degrading enzymes. App Microbiol Biotechnol. 2008;81:399-417.

9. Mayfield MB, Kishi K, Alic M, Gold MH. Homologous expression of recombinant manganese peroxidase in Phanerochaete chrysosporium. Appl Environ Microb. 1994;60:4303-9.

10. Irie T, Honda Y, Watanabe T, Kuwahara M. Homologous expression of recombinant manganese peroxidase genes in ligninolytic fungus Pleurotus ostreatus. Appl Microbiol Biotechnol. 2001:55:566-70.

11. Gu L, Lajoie C, Kelly C. Expression of a Phanerochaete chrysosporium manganese peroxidase gene in the yeast Pichia pastoris. Biotechnol Progr. 2003;19:1403-9.

12. Whitwam R, Ming T. Heterologous expression and reconstitution of funga Mn peroxidase. Arch Biochem Biophys. 1996;333:439-46.
13. Ambert-Balay K, Dougherty M, Tien M. Reactivity of manganese peroxidase: site-directed mutagenesis of residues in proximity to the porphyrin ring. Arch Biochem Biophys. 2000;382:89-94.

14. Ignatova Z, Mahsunah A, Georgieva M, Kasche V. Improvement of posttranslational bottlenecks in the production of penicillin amidase in recombinant Escherichia coli strains. App Environ Microb. 2003:69:1237-45.

15. Järvinen J, Taskila S, Isomäki R, Ojamo H. Screening of white-rot fungi manganese peroxidases: a comparison between the specific activities of the enzyme from different native producers. AMB Express. 2012;2:62.

16. Pacheco B, Crombet L, Loppnau P, Cossar D. A screening strategy for heterologous protein expression in Escherichia coli with the highest return of investment. Protein Expres Purif. 2012;81:33-41.

17. Shaw MK, Ingraham JL. Synthesis of macromolecules by Escherichia coli near the minimal temperature for growth. J Bacteriol. 1967;94:157-64.

18. Basu A, Li X, Leong SSJ. Refolding of proteins from inclusion bodies: rational design and recipes. Appl Microbiol Biotechnol. 2011;92:241-51.

19. Prasad S, Khadatare PB, Roy I. Effect of chemical chaperones in improving the solubility of recombinant proteins in Escherichia coli. Appl Environ Microb. 2011;77:4603-9.

20. Schlieker C, Bukau B, Mogk A. Prevention and reversion of protein aggregation by molecular chaperones in the $E$. coli cytosol: implications for their applicability in biotechnology. J Biotehnol. 2002;96:13-21.

21. Jenkins TM, Engelman A, Ghirlando R, Craigie R. A soluble active mutant of HIV-1 integrase. J Biol Chem. 1996;271:7712-8.

22. Chen WT, Zheng $L L$, Jia $R$, Wang N. Cloning and expression of a new manganese peroxidase from Irpex lacteus F17 and its application in decolorization of reactive black 5. Process Biochem. 2015;50:1748-59.

23. Zhao XS, Huang XJ, Yao JT, Zhou Y, Jia R. Fungal growth and manganese peroxidase production in a deep tray solid-state bioreactor, and in vitro decolorization of poly R-478 by MnP. J Microbiol Biotech. 2014;25:803-13.

24. Herrero AM. Raman spectroscopy for monitoring protein structure in muscle food systems. Crit Rev Food Sci. 2008:48:512-23.

25. Fakoussa RM, Hofrichter M. Biotechnology and microbiology of coal degradation. Appl Microbiol Biotechnol. 1999:52:25-40.

26. Perie FH, Sheng D, Gold MH. Purification and characterization of two manganese peroxidase isozymes from the white-rot basidiomycete Dichomitus squalens. Biochim Biophys Acta. 1996;1297:139-48.

27. Ufot UF, Akpanabiatu MI. An engineered Phlebia radiata manganese peroxidase: expression, refolding, purification and preliminary characterization. Am J Resp Cell Mol. 2012;2:359-70.

28. Liu Y, Deng RJ, Hao MF, Yan H, Yang WM. Orthogonal design study on factors effecting on fibers diameter of melt electrospinning. Polym Eng Sci. 2010;50(10):2074-8.

29. Jiao Y, Han Y, Li X, Fang YG, Liu ZH, Zhou WN, Zhou JC, Wu ZC, Yang JH, Li SY, Meng FY, Xu WW. Comparison of body, auricular, and abdominal acupuncture treatments for insomnia differentiated as internal harassment of phlegm-heat syndrome: an orthogonal design. Evid-Based Compl Alt. 2015:5:1-9.

30. Smith AT, Santama N, Dacey S, Edwards M, Bray RC, Thorneley RNF, Burke $J F$. Expression of a synthetic gene for horseradish peroxidase $C$ in Escherichia coli and folding and activation of the recombinant enzyme with $\mathrm{Ca}^{2+}$ and heme. J Biol Chem. 1990;265:13335-43.

31. Miki Y, Morales M, Ruiz-Dueñas FJ, Martínez MJ, Wariishi H, Martínez AT. Escherichia coli expression and in vitro activation of a unique ligninolytic peroxidase that has a catalytic tyrosine residue. Protein Expres Purif. 2009;68:208-14

32. Schein $\mathrm{CH}$. Production of soluble recombinant proteins in bacteria. Bio Technology. 1989;7:1141-9.

33. Esposito D, Chatterjee DK. Enhancement of soluble protein expression through the use of fusion tags. Curr Opin Biotech. 2006;17:353-8.

34. Mohorčič $M$, Benčina $M$, Friedrich J, Jerala R. Expression of soluble versatile peroxidase of Bjerkandera adusta in Escherichia coli. Bioresource Technol. 2009;100:851-8

35. Tang JB, Yang HM, Song SL, Zhu P, Ji AG. Effect of glycine and Triton X-100 on secretion and expression of ZZ-EGFP fusion protein. Food Chem 2008:108:657-62

36. Choi JH, Lee SY. Secretory and extracellular production of recombinant proteins using Escherichia coli. Appl Microbiol Biotechnol. 2004:64:625-35.

37. Alibolandi $M$, Mirzahoseini $H$. Chemical assistance in refolding of bacterial inclusion bodies. Biochemistry Research International. 2011: doi:10.1155/ 2011/631607 
38. Thomas JG, Baneyx FD. Divergent effects of chaperone overexpression and ethanol supplem entation on in clusion body formation in recombinant Escherichia coli. Protein Expr Purif. 1997;11(3):289-96.

39. Steczko J, Donoho GA, Dixon JE, Sugimoto T, Axelrod B. Effect of ethanol and low-mperature culture on expression of soybean lipoxygenase $L-1$ in Escherichia coli. Protein Expr Purif. 1991;2:221-7.

40. Samuel D, Kumar TKS, Ganesh G, Jayaraman G, Yang PW, Chang MM, Trivedi VD, Wang SL, Hwang KC, Chang DK, Yu C. Proline inhibits aggregation during protein refolding. Protein Sci. 2000;9:344-52.

41. Pollitt S, Zalkin H. Role of primary structure and disulfide bond formation in b-lactamase secretion. J Bacteriol. 1983;153:27-32.

42. Makrides SC. Strategies for achieving high-level expression of genes in Escherichia coli. Microbiol Rev. 1996;60:512-38.

43. Yang JB, Moyana T, Mackenzie S, Xia Q, Xiang J. One hundred seventy-fold increase in excretion of an FV fragment-tumor necrosis factor alpha fusion protein (sFV/TNF-alpha) from Escherichia coli caused by the synergistic effects of glycine and triton X. App Environ Microb. 1998;64(8):2869-74.

44. Pérez-Boada M, Doyle WA, Ruiz-Dueñas FJ, Martínez MJ, Martínez AT. Expression of Pleurotus eryngii versatile peroxidase in Escherichia coli and optimisation of in vitro folding. Enzyme Microb Tech. 2002;30:518-24.

45. Ninomiya R, Zhu B, Kojima T, Iwasaki Y, Nakano H. Role of disulfide bond isomerase $\mathrm{DsbC}$, calcium ions, and hemin in cell-free protein synthesis of active manganese peroxidase isolated from Phanerochaete chrysosporium. J Biosci Bioeng. 2014;117:652-7.

46. Sutherland GRJ, Aust SD. The effects of calcium on the thermal stability and activity of manganese peroxidase. Arch Biochem Biophys. 1996:332:128-34.

47. Sklenar J, Niku-Paavola ML, Santos S, Man P, Kruus K, Novotny C. Isolation and characterization of novel pl $4.8 \mathrm{MnP}$ isoenzyme from white-rot fungus Irpex lacteus. Enzyme Microb Tech. 2010;46:550-6.

48. Boer CG, Obici L, Souza CGM, Peralta RM. Purification and some properties of Mn peroxidase from Lentinula edodes. Process Biochem. 2006;41:1203-7.

49. Knop D, Yaeden O, Hasar Y. The ligninolytic peroxidases in the genus pleurotus: divergence in activities, expression, and potential applications. Appl Microbiol Biotechnol. 2015;99:1025-38.

50. Kishi K, Hildebrand DP, Someren MK, Gettemy J, Mauk AJ, Gold MH. Sitedirected mutations at phenylalanine-190 of manganese peroxidase: effects on stability, function, and coordination. Biochem. 1997;36:4266-77.

51. Aceves MA, Baratto MC, Basosi R, Vazquez-Duhalt R, Pogni R. Spectroscopic characterization of a manganese-lignin peroxidase hybrid isozyme produced by Bjerkandera adusta, in the absence of manganese: evidence of a protein centred radical by hydrogen peroxide. J Mol Catal B-Enzym. 2001; 16:159-67.

52. Mendes S, Brissos V, Gabriel A, Catarino T, Turner DL. An integrated view of redox and catalytic properties of B-type PpDyP from Pseudomonas putida, MET94 and its distal variants. Arch Biochem Biophy. 2015;574:99-107.

53. Rygula A, Majzner K, Marzec KM, Kaczor A, Pilarczyk M. Raman spectroscopy of proteins: a review. J Raman Spectrosc. 2013;44:1061-76.

54. Chihi ML, Mession JL, Sok N, Saurel R. Heat-induced soluble protein aggregates from mixed pea globulins and $\beta$-lactoglobulin. J Agr Food Chem. 2016:64:2780-91.

55. Wang JJ, Liu GY, Liu G, Zeng QH, Shen X, Hou Y, Li L, Hu SQ. The soluble recombinant N-terminal domain of HMW $1 \mathrm{D} \times 5$ and its aggregation behavior. Food Res Int. 2015;78:201-8.

\section{Submit your next manuscript to BioMed Central and we will help you at every step:}

- We accept pre-submission inquiries

- Our selector tool helps you to find the most relevant journal

- We provide round the clock customer support

- Convenient online submission

- Thorough peer review

- Inclusion in PubMed and all major indexing services

- Maximum visibility for your research

Submit your manuscript at www.biomedcentral.com/submit

) Biomed Central 